Article

\title{
Morphology effect of zirconia support on the catalytic performance of supported Ni catalysts for dry reforming of methane
}

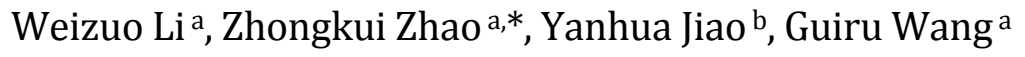 \\ a State Key Laboratory of Fine Chemicals, Department of Catalysis Chemistry and Engineering, School of Chemical Engineering, Dalian University of \\ Technology, Dalian 116024, Liaoning, China \\ b College of Material Chemistry and Chemical Engineering, Hangzhou Normal University, Hangzhou 310036, Zhejiang, China
}

\section{A R T I C L E I N F}

\section{Article history:}

Received 29 August 2016

Accepted 30 September 2016

Published 5 December 2016

\section{Keywords:}

Ni-based catalyst

$\mathrm{ZrO}_{2}$ support

Hierarchical structure

Morphology effect

Dry reforming of methane

Synthesis gas

Coke resistance

\begin{abstract}
A B S T R A C T
An immature pinecone shaped hierarchically structured zirconia $\left(\mathrm{ZrO}_{2}\right.$-ipch) and a cobblestone-like zirconia nanoparticulate $\left(\mathrm{ZrO}_{2}-\mathrm{cs}\right)$, both with the monoclinic phase (m-phase), were synthesized by the facile hydrothermal method and used as the support for a Ni catalyst for the dry reforming of methane (DRM) with $\mathrm{CO}_{2}$. $\mathrm{ZrO}_{2}$-ipch is a much better support than $\mathrm{ZrO}_{2}$-cs and the traditional $\mathrm{ZrO}_{2}$ irregular particles made by a simple precipitation method ( $\mathrm{ZrO}_{2}$-ip). The supported Ni catalyst on $\mathrm{ZrO}_{2}$-ipch $\left(\mathrm{Ni} / \mathrm{ZrO}_{2}\right.$-ipch) exhibited outstanding catalytic activity and coke-resistant stability compared to the ones on $\mathrm{ZrO}_{2}$-cs $\left(\mathrm{Ni} / \mathrm{ZrO}_{2}\right.$-cs) and $\mathrm{ZrO}_{2}$-ip $\left(\mathrm{Ni} / \mathrm{ZrO}_{2}\right.$-ip). Ni/ZrO $\mathrm{Zr}_{2}$-ip exhibited the worst catalytic performance. The origin of the significantly enhanced catalytic performance was revealed by characterization including XRD, $\mathrm{N}_{2}$ adsorption measurement (BET), TEM, $\mathrm{H}_{2}$-TPR, CO chemisorption, $\mathrm{CO}_{2}$-TPD, XPS and TGA. The superior catalytic activity of $\mathrm{Ni} / \mathrm{ZrO}_{2}$-ipch to $\mathrm{Ni} / \mathrm{ZrO}_{2}$-cs or $\mathrm{Ni} / \mathrm{ZrO}_{2}$-ip was ascribed to a higher $\mathrm{Ni}$ dispersion, increased reducibility, enhanced oxygen mobility, and more basic sites with a higher strength, which were due to the unique hierarchically structural morphology of the $\mathrm{ZrO}_{2}$-ipch support. $\mathrm{Ni} / \mathrm{ZrO}_{2}$-ipch exhibited better stability for the DRM reaction than $\mathrm{Ni} / \mathrm{ZrO}_{2}$-ip, which was ascribed to its higher resistance to $\mathrm{Ni}$ sintering due to a strengthened metal-support interaction and the confinement effect of the mesopores and coke deposition resistance. The higher coking resistance of $\mathrm{Ni} / \mathrm{ZrO}_{2}$-ipch for the $\mathrm{DRM}$ reaction in comparison with $\mathrm{Ni} / \mathrm{ZrO}_{2}$-ip orignated from the coke-removalability of the higher amount of lattice oxygen and more basic sites, confirmed by XPS and $\mathrm{CO}_{2}$-TPD analysis, and the stabilized Ni on the $\mathrm{Ni} / \mathrm{ZrO}_{2}$-ipch catalyst by the confinement effect of the mesopores of the hierarchical $\mathrm{ZrO}_{2}$-ipch support. The superior catalytic performance and coking resistance of the $\mathrm{Ni} / \mathrm{ZrO}_{2}$-ipch catalyst makes it a promising candidate for synthesis gas production from the DRM reaction.
\end{abstract}

(C) 2016, Dalian Institute of Chemical Physics, Chinese Academy of Sciences. Published by Elsevier B.V. All rights reserved.

\section{Introduction}

The dry reforming of methane (DRM) has attracted considerable attention because $\mathrm{CO}_{2}$ is the primary greenhouse that has brought about significant climate change, and methane as the main component of natural gas used in combustion leads to a great deal of $\mathrm{CO}_{2}$ emission. Thus, the DRM reaction converts two greenhouse gases to the industrially important synthesis

\footnotetext{
* Corresponding author. Tel/Fax: +86-411-84986354; E-mail: zkzhao@dlut.edu.cn

This work was financially supported by the Joint Fund of Coal, set up by National Natural Science Foundation of China and Shenhua Co., Ltd. (U1261104), the National Natural Science Foundation of China (21276041), the Program for New Century Excellent Talents in University (NCET-12-0079), the Natural Science Foundation of Liaoning Province (2015020200), the Fundamental Research Funds for the Central Universities (DUT15LK41), and the Science and Technology Development Program of Hangzhou (20130533B14).

DOI: 10.1016/S1872-2067(16)62540-8 | http://www.sciencedirect.com/science/journal/18722067 | Chin. J. Catal., Vol. 37, No. 12, December 2016
} 
gas $\left(\mathrm{H}_{2}\right.$ and $\left.\mathrm{CO}\right)$, which serves as the platform for downstream liquid fuels and valuable chemicals [1-8].

Although the noble metal catalysts have exhibited high catalytic performance and low carbon deposition, their high cost and low availability limit their large scale application in industry [9-13]. Ni-based catalysts have been established as potential catalysts for industrial application in synthesis gas production from the DRM reaction owing to their low cost and comparable activity and selectivity to noble metal catalysts. Unfortunately, Ni-based catalysts have a bottleneck issue of rapid deactivation due to the carbon deposition as well as the sintering and oxidation of metallic Ni under the harsh reaction conditions [14-22]. Among these, carbon deposition has been accepted as the main reason of catalyst deactivation [23-25]. Many reports have focused on retarding coke deposition [7,26-31]. Typically, the coke can be efficiently suppressed by Ni-support interface tuning [32] and enhancing heat transfer $[33,34]$. There is agreement in the references that the coke originates mainly from the two reactions of the decomposition of methane and the Boudouard reaction of $\mathrm{CO}$, which are strongly dependent on the nature of support.

In the references [35-39], $\mathrm{ZrO}_{2}$ has been widely used as the catalyst support for diverse transformations including DRM, owing to its high thermal stability, unique acid-base properties and surface oxygen mobility. It was found that the crystalline phase, crystalline size, and pore structure of the $\mathrm{ZrO}_{2}$ support significantly affected the catalytic performance of the supported catalysts [40-42]. Zheng et al. [43] compared the catalytic performance of supported $\mathrm{Ni}$ catalysts on $\mathrm{ZrO}_{2}$ prepared by flowing nitrogen $\left(\mathrm{ZrO}_{2}-\mathrm{AN}\right)$ and air $\left(\mathrm{ZrO}_{2}-\mathrm{CP}\right)$. It was found that $\mathrm{Ni} / \mathrm{ZrO}_{2}-\mathrm{AN}$ exhibited much higher stability than $\mathrm{Ni} / \mathrm{ZrO}_{2}-\mathrm{CP}$, which was ascribed to the different nature but not to the amount of coke. Change et al. [44] confirmed that the simultaneous alteration of the support and $\mathrm{Ni}$ surface of $\mathrm{Ni} / \mathrm{ZrO}_{2}$ with a Ce modifier and a Ca promoter led to a high performance catalyst, mainly ascribed to a synergy effect of the Ca promoter and Ce modifier for coke resistance and high temperature catalyst aging. Gonzalez-Delacruz et al. [3] found that the size of metallic $\mathrm{Ni}$ of the $\mathrm{Ni} / \mathrm{ZrO}_{2}$ catalyst can be efficiently tuned by a $\mathrm{H}_{2} / \mathrm{CO}$ treatment, which significantly affects the catalytic performance for DRM. Xu et al. [45] explored the size effect of $\mathrm{ZrO}_{2}$ support particles on the catalyst and catalytic performance of a $\mathrm{Ni} / \mathrm{ZrO}_{2}$ catalyst for the utilization of natural gas through dry reforming by $\mathrm{CO}_{2}$, and found that the supported $\mathrm{Ni}$ catalyst on the $\mathrm{ZrO}_{2}$ support with a smaller particle size exhibited much higher catalytic stability, ascribed to the enhancing effect of reducing the particle size on oxygen transfer ability. It was found that the shape of the supports (e.g., $\mathrm{CeO}_{2}, \mathrm{ZnO}$, and $\mathrm{La}_{2} \mathrm{O}_{3}$ ) strongly affected their catalytic performance [47-49]. In many cases, the morphology effect of $\mathrm{CeO}_{2}$ and doped $\mathrm{CeO}_{2}$ has been widely used on a catalyst support to promote the activation of $\mathrm{CO}_{2}$ and oxidative removal of surface carbon species [7,46,49-51]. However, to the best our knowledge, few reports regarding the morphology effect of the $\mathrm{ZrO}_{2}$ support on $\mathrm{Ni}$-based catalysts for DRM reaction can be found.

Herein, we successfully prepared two $\mathrm{m}-\mathrm{ZrO}_{2}$ supports with different morphologies including an immature pinecone shaped hierarchically structured zirconia $\left(\mathrm{ZrO}_{2}\right.$-ipch) and a cobblestone-like zirconia nanoparticulate $\left(\mathrm{ZrO}_{2}-\mathrm{cs}\right)$, and tested the catalytic performance of the supported $\mathrm{Ni}$ catalysts ( $\mathrm{Ni} / \mathrm{ZrO}_{2}$-ipch and $\mathrm{Ni} / \mathrm{ZrO}_{2}$-cs) on the two supports for the DRM reaction. $\mathrm{Ni} / \mathrm{ZrO}_{2}$-ip was also prepared and tested for comparison. It was found that the $\mathrm{Ni} / \mathrm{ZrO}_{2}$-ipch catalyst exhibited much higher catalytic activity than $\mathrm{Ni} / \mathrm{ZrO}_{2}$-cs or $\mathrm{Ni} / \mathrm{ZrO}_{2}$-ip, and it also exhibited higher coke-resistant stability. Characterization techniques including X-ray diffraction (XRD), $\mathrm{N}_{2}$ adsorption measurement (BET), transmission electron microscopy (TEM), temperature-programmed reduction of hydrogen ( $\mathrm{H}_{2}$-TPR), $\mathrm{CO}$ chemisorption, temperature-programmed desorption of $\mathrm{CO}_{2}$ ( $\mathrm{CO}_{2}$-TPD), X-ray photoelectron spectroscopy (XPS) and thermogravimetric analysis (TGA) were employed to investigate the morphology effect of the $\mathrm{ZrO}_{2}$ support on the supported Ni catalyst for DRM. The origin of the high activity and coke-resistant stability of $\mathrm{Ni} / \mathrm{ZrO}_{2}$-ipch was explored.

\section{Experimental}

\subsection{Catalyst preparation}

All chemicals (Sinopharm Chemical Reagent Co., Ltd) were used as purchased without further purification. For $\mathrm{ZrO}_{2}$-ipch, $3.22 \mathrm{~g}$ ( $7.5 \mathrm{mmol})$ of $\mathrm{Zr}\left(\mathrm{NO}_{3}\right)_{4} \cdot 5 \mathrm{H}_{2} \mathrm{O}$ was dissolved in de-ionized water under magnetic stiring, followed by adding $1.5 \mathrm{~g}(10.7$ mmol) of hexamethylenetetramine aqueous solution to the $\mathrm{Zr}\left(\mathrm{NO}_{3}\right)_{4}: 5 \mathrm{H}_{2} \mathrm{O}$ aqueous solution. Then $\mathrm{NH}_{4} \mathrm{~F}$ was introduced into the above mixture. The resulting solution was transferred into a Teflon-lined autoclave and hydrothermally treated for 24 h. After the autoclave was cooled down to room temperature, the suspension was separated by filtration, washed with de-ionized water several times, and then dried at $105^{\circ} \mathrm{C}$ overnight. The solid was subsequently calcinated at $550^{\circ} \mathrm{C}$ for $5 \mathrm{~h}$ in a muffle furnace, and $\mathrm{ZrO}_{2}$-ipch was otained. For $\mathrm{ZrO}_{2}$-cs, asolution containing $3.22 \mathrm{~g}$ (7.5 mmol) of $\mathrm{Zr}\left(\mathrm{NO}_{3}\right)_{4} \cdot 5 \mathrm{H}_{2} \mathrm{O}$ was transferred into a Teflon-lined autoclave and was hydrothermally treated at the same conditions as above. After the autoclave was naturally cooled down to room temperature (RT), the solid was recovered by filtration, washed with de-ionized water several times, and then dried at $105{ }^{\circ} \mathrm{C}$ overnight. The solid was calcined at $550{ }^{\circ} \mathrm{C}$ for $5 \mathrm{~h}$ in a muffle furnace, and the $\mathrm{ZrO}_{2}$-cs sample was obtained. For comparison, a traditional $\mathrm{ZrO}_{2}$-ip support was also prepared by the common precipitation method by using $35 \%$ ammonia as precipitant.

The supported $\mathrm{Ni}$ catalysts on the $\mathrm{ZrO}_{2}$-ipch, $\mathrm{ZrO}_{2}$-cs and $\mathrm{ZrO}_{2}$-ip supports (10\% Ni loading) were prepared by using the previously established LA-IWI method [52]. The $\mathrm{NiO} / \mathrm{ZrO}_{2}-$ ipch, $\mathrm{NiO} / \mathrm{ZrO}_{2}$-cs and $\mathrm{NiO} / \mathrm{ZrO}_{2}$-ip samples were reduced at $850{ }^{\circ} \mathrm{C}$ for $2 \mathrm{~h}$ under a mixture of $20 \% \mathrm{H}_{2}$ in $80 \% \mathrm{~N}_{2}$ at a flow rate of $30 \mathrm{~mL} / \mathrm{min}$ to obtain the reduced samples, which were denoted as $\mathrm{Ni} / \mathrm{ZrO}_{2}$-ipch, $\mathrm{Ni} / \mathrm{ZrO}_{2}$-cs and $\mathrm{Ni} / \mathrm{ZrO}_{2}$-ip, respectively.

\subsection{Catalyst characterization}

TEM images were obtained by using a Tecnai F30 HRTEM 
instrument (FEI Corp.) at an acceleration voltage of $300 \mathrm{kV}$. The sample was dispersed in ethanol with ultrasonic treatment for $10 \mathrm{~min}$, and a drop of the suspension was placed on a copper grid for TEM observation. FE-SEM experiments were performed on a JEOL JSM-5600LV SEM/EDX instrument.

Nitrogen adsorption and desorption isotherms were determined on a Beishide apparatus Model 3H-2000PS1 at $-196{ }^{\circ} \mathrm{C}$. The specific surface areas were calculated by the Brunauer-Emmett-Teller (BET) method, and the mesopore size distribution was calculated from the adsorption branch of the isotherm by the BJH model.

XRD patterns were collected from $10^{\circ}$ to $80^{\circ}$ at a step width of $0.02^{\circ}$ using a Rigaku Automatic X-ray Diffractometer (D/Max 2400) equipped with a $\mathrm{Cu} K_{\alpha}$ source $(\lambda=0.15406 \mathrm{~nm})$. The average crystallite size was estimated on the basis of the Scherrer formula from the characteristic diffraction peaks by the MDI Jade 5 software.

TGA analysis was conducted to study the amount of coke deposited on the spent $\mathrm{ZrO}_{2}$-ipch and $\mathrm{ZrO}_{2}$-ip catalysts using a Perkin-Elmer STA 6000 with a heating rate of $10^{\circ} \mathrm{C} / \mathrm{min}$ from 30 to $800^{\circ} \mathrm{C}$ in an air stream.

The Ni dispersion of the two catalysts was measured by CO titration at $35{ }^{\circ} \mathrm{C}$ using a Builder PCA-1200 Pulsar TPR/TPD equipment by pulse chemisorption $(300 \mu \mathrm{L}$ for each pulse, $10 \%$ C0/90\% He, purity of $\mathrm{He}$ is $99.999 \%)$. The catalyst ( $100 \mathrm{mg}$ ) was reduced in situ with $\mathrm{H}_{2}$ at $850{ }^{\circ} \mathrm{C}$ for $1.5 \mathrm{~h}$, then flushed at $400{ }^{\circ} \mathrm{C}$ with $\mathrm{He}$ for $50 \mathrm{~min}$. After pre-reduction, the catalyst was cooled to $30^{\circ} \mathrm{C}$ and $\mathrm{CO}$ chemisorption was carried out. The $\mathrm{Ni}$ dispersion was calculated by

$$
D_{\mathrm{M}}=100 \% \times\left(\left(V_{\mathrm{s}} \times \mathrm{SF}\right) /(\mathrm{SW} \times 22414)\right) \times \mathrm{MW}
$$

where $D_{\mathrm{M}}, V_{\mathrm{S}}, \mathrm{SF}, \mathrm{SW}$ and MW were metal dispersion (\%), volume of active gas chemisorbed $\left(\mathrm{cm}^{3}\right.$ at STP), stoichiometric factor, catalyst mass (g), and molecular mass of metallic $\mathrm{Ni}$ (g/mol), respectively [53].

$\mathrm{H}_{2}$-TPR experiments were performed on a Builder PCA-1200 automated system. $100 \mathrm{mg}$ of catalyst was placed in a U-shape quartz tube in a temperature-controlled oven. The catalyst was first purged under $30 \mathrm{~cm}^{3} / \mathrm{min}$ of Ar flow at $300{ }^{\circ} \mathrm{C}$ for $30 \mathrm{~min}$ (using a ramp rate of $10{ }^{\circ} \mathrm{C} / \mathrm{min}$ ) and then cooled down to RT. After that, it was reduced with a $10 \% \mathrm{H}_{2}-90 \% \mathrm{Ar}$ mixture $(30 \mathrm{~mL} / \mathrm{min})$ by heating to $800{ }^{\circ} \mathrm{C}$ at a ramp rate of 10 ${ }^{\circ} \mathrm{C} / \mathrm{min}$. The amount of hydrogen consumption was measured using a thermal conductivity detector.

$\mathrm{CO}_{2}$-TPD was performed using a Builder PCA-1200 automated instrument. The catalyst was pre-reduced under a $10 \%$ $\mathrm{H}_{2} /$ Ar mixture gas flow ( $30 \mathrm{~mL} / \mathrm{min}$ ) by ramping to $800{ }^{\circ} \mathrm{C}(10$ ${ }^{\circ} \mathrm{C} / \mathrm{min}$ ). Then, the system was purged with He at $800{ }^{\circ} \mathrm{C}$ for 30 min, and then cooled down to RT. The adsorption of $\mathrm{CO}_{2}$ was performed at $50{ }^{\circ} \mathrm{C}$ in a pure $\mathrm{CO}_{2}(99.999 \%)$ flow with a rate of $30 \mathrm{~mL} / \mathrm{min}$, and the catalyst was purged with a He stream at 50 ${ }^{\circ} \mathrm{C}$. After that, the system was cooled down to RT in a He stream until the baseline was steady. Finally, $\mathrm{CO}_{2}$-TPD was performed with a ramp of $10 \mathrm{~mL} / \mathrm{min}$ from the RT to $800{ }^{\circ} \mathrm{C}$ in a 30 $\mathrm{mL} / \mathrm{min}$ He stream.

The XPS experiments were carried out on an ESCALAB 250 XPS system with a monochromatized $\mathrm{Al} K_{a}$ X-ray source $(15 \mathrm{kV}$, $150 \mathrm{~W}, 500 \mu \mathrm{m}$, pass energy $=50 \mathrm{eV}$ ). The binding energy was calibrated by the $\mathrm{C} 1 \mathrm{~s}$ photoelectron peak at $284.6 \mathrm{eV}$. The binding energy of $01 s$ was analyzed using the Shirley baseline correction method.

\subsection{Catalytic performance measurement}

The catalytic performance measurement of the catalysts was performed in a quartz tube fixed-bed reactor $(6 \mathrm{~mm}$ O.D. and $4 \mathrm{~mm} \mathrm{I}$. D.) at atmospheric pressure. Typically, $30 \mathrm{mg}$ catalyst with the 40-60 mesh particle size was loaded between two quartz wool plugs. The temperatures were measured using $\mathrm{K}$ Type thermocouples and controlled by a PID controller. Before the reaction, the catalyst was reduced at $850{ }^{\circ} \mathrm{C}$ for $2 \mathrm{~h}$ using a mixture of $20 \% \mathrm{H}_{2}$ in $80 \% \mathrm{~N}_{2}$ at a flow rate of $30 \mathrm{~mL} / \mathrm{min}$. The reaction feed contained $\mathrm{CH}_{4}, \mathrm{CO}_{2}$ and $\mathrm{N}_{2}\left(\mathrm{~N}_{2}\right.$ was used as the internal standard gas), which was controlled by mass flow controllers. The reforming reaction was performed at 650, 750 and $850{ }^{\circ} \mathrm{C}$, and the $\mathrm{N}_{2}$ was used an internal standard to calculate the $\mathrm{CH}_{4}$ and $\mathrm{CO}_{2}$ conversion. The effluent gas was passed through a trap and then analyzed by a gas chromatograph online with a molecular sieve column and a Porapak Q column. The stability was tested by using the following conditions: $m_{\text {cat }}$ $=30 \mathrm{mg}, \mathrm{CH}_{4}: \mathrm{CO}_{2}: \mathrm{N}_{2}=1: 1: 3, \mathrm{GHSV}=100000 \mathrm{~mL} \mathrm{~h}^{-1} \mathrm{~g}^{-1}, T=850$ ${ }^{\circ} \mathrm{C}$ and atmospheric pressure. The conversions of $\mathrm{CH}_{4}\left(\mathrm{X}_{\mathrm{CH} 4}\right)$ and $\mathrm{CO}_{2}\left(X_{\mathrm{CO} 2}\right)$, the selectivity of $\mathrm{H}_{2}\left(\mathrm{~S}_{\mathrm{H} 2}\right)$, as well as $\mathrm{H}_{2} / \mathrm{CO}$ ratio were calculated as follows:

$$
\begin{gathered}
X_{\mathrm{CH} 4}=\left(F_{\mathrm{CH} 4, \text { in }}-F_{\mathrm{CH} 4, \text { out }}\right) / F_{\mathrm{CH} 4, \text { in }} \times 100 \% \\
X_{\mathrm{CO} 2}=\left(F_{\mathrm{CO} 2, \text { in }}-F_{\mathrm{CO} 2, \text { out }}\right) / F_{\mathrm{CO} 2 \text {,in }} \times 100 \% \\
S_{\mathrm{H} 2}=\mathrm{F}_{\mathrm{H} 2, \text { out }} / 2\left(F_{\mathrm{CH} 4 \text {,in }}-F_{\mathrm{CH} 4, \mathrm{out}}\right) \times 100 \% \\
\mathrm{H}_{2} / \mathrm{CO}=\left[\mathrm{H}_{2}\right]_{\text {out }} /[\mathrm{CO}]_{\text {out }}
\end{gathered}
$$

\section{Results and discussion}

\subsection{Morphology and texture of the $\mathrm{ZrO}_{2}$ supports}

The morphology of the three synthesized $\mathrm{ZrO}_{2}$ supports was examined by FE-SEM. Fig. (1a-c) displays typical FE-SEM images. From Fig. 1(a), a panoramic view revealed particles with different shapes including rice-like ones for $\mathrm{ZrO}_{2}$-ipch. The enlarged FE-SEM image of $\mathrm{ZrO}_{2}$-ipch (inset in Fig. 1(a)) further suggested that $\mathrm{ZrO}_{2}$-ipch has an immature pinecone shaped hierarchical structure composed of $\mathrm{ZrO}_{2}$ nanoparticles. However, $\mathrm{ZrO}_{2}$-cs has cobblestone-like agglomerated $\mathrm{ZrO}_{2}$ nanoparticles (Fig. 1(b)). Fig. 1(c) shows that $\mathrm{ZrO}_{2}$-ip has an aggregate shape of iregular particles. The TEM images of $\mathrm{ZrO}_{2}$-ipch, $\mathrm{ZrO}_{2}$-cs and $\mathrm{ZrO}_{2}$-ip (Fig. $1(\mathrm{~d}-\mathrm{f}$ )) present further views of their morphology. From Fig. 1(d), the hierarchical structure feature with mesopores of $\mathrm{ZrO}_{2}$-ipch can be further confirmed. More interestingly, in Fig. 1(e), the nanopores (less than $20 \mathrm{~nm}$ ) of the cobblestone-like agglomerated $\mathrm{ZrO}_{2}$ nanoparticles can be clearly seen. From Fig. 1(f), the structural characteristic of aggregation of $\mathrm{ZrO}_{2}$-ip composed of irreggular particles can be further confirmed. From the above, it was confirmed that an immature pinecone shaped hierarchical structure with mesopores $\left(\mathrm{ZrO}_{2}\right.$-ipch) and a cobblestone-like agglomerated $\mathrm{ZrO}_{2}$ nanoparticles with nanopores in the nanoparticles $\left(\mathrm{ZrO}_{2}-\mathrm{cs}\right)$ were successfully prepared. The 


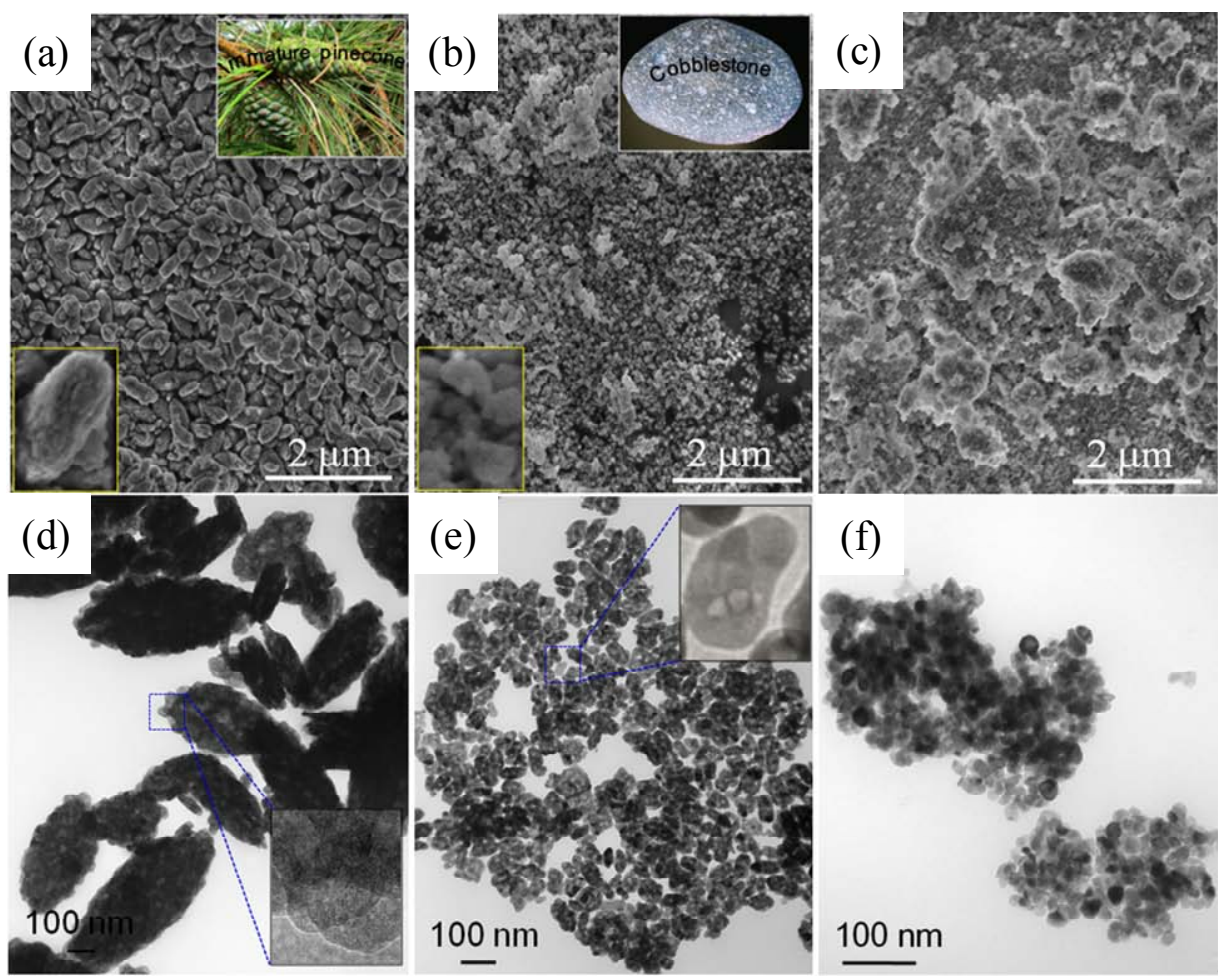

Fig. 1. FE-SEM (a-c) and TEM (d-f) images of $\mathrm{ZrO}_{2}$-ipch (a,d), $\mathrm{ZrO}_{2}$-cs (b,e) and $\mathrm{ZrO}_{2}$-ip (c,f) samples. Insets in Fig. 1(d,e) are the magnified images of selected regions.

textural properties of the two synthesized $\mathrm{ZrO}_{2}$ supports were measured by nitrogen adsorption.

Fig. 2 presents the nitrogen adsorption of $\mathrm{ZrO}_{2}$-ipch, $\mathrm{ZrO}_{2}$-cs and $\mathrm{ZrO}_{2}$-ip (the insets in Fig. 2(a) are specific surface area and pore volume). The most probable pore size are listed in Table 1. In Fig. 2(a), the isotherm of $\mathrm{ZrO}_{2}$-ipch is of type IV with a $\mathrm{H3}$ hysteresis loop, indicating the presence of narrow slit-shaped mesopores (less than $20 \mathrm{~nm}$ ) [54,55], which agreed with the TEM observation (Fig. 1(a)). The isotherm corresponding to the $\mathrm{ZrO}_{2}$-cs support showed the type IV feature with a H3 hysteresis loop. However, in comparison with the isotherm of $\mathrm{ZrO}_{2}$-ipch, there was a capillary condensation step at 0.9-0.95 in the high relative pressure region, indicating the formation of macropores [56]. In Fig. 2(b) and in Table 1, the mesopores with the size $4 \mathrm{~nm}$ can be ascribed to the pores of the cobblestone-like nanoparticulates shown in Fig. 1(b), whereas the macropores with the size of 20-70 nm with bimodal pores (12.4 and $42.0 \mathrm{~nm}$ ) resulted from the pores of agglomerated cobblestone-like nanoparticles. $\mathrm{ZrO}_{2}$-ip has the most probable pore diameter of $12.8 \mathrm{~nm}$. The hierarchically structured $\mathrm{ZrO}_{2}$-ipch has a lower surface area $\left(15.3 \mathrm{~m}^{2} / \mathrm{g}\right.$, the inset in Fig. 2(a)) and smaller pore volume $\left(0.07 \mathrm{~cm}^{3} / \mathrm{g}\right)$ than those of $\mathrm{ZrO}_{2}$-cs $\left(33.2 \mathrm{~m}^{2} / \mathrm{g}\right.$ and $0.29 \mathrm{~cm}^{3} / \mathrm{g}$, respectively) and $\mathrm{ZrO}_{2}$-ip $\left(39.5 \mathrm{~m}^{2} / \mathrm{g}\right.$ and $0.16 \mathrm{~cm}^{3} / \mathrm{g}$, respectively), which might be ascribed to the denser accumulation of nanoparticles in the hierarchical structure.

The crystalline structure of the three synthesized supports was investigated by XRD analysis. Fig. 3 presents XRD patterns of the $\mathrm{ZrO}_{2}$-ipch, $\mathrm{ZrO}_{2}$-cs and $\mathrm{ZrO}_{2}$-ip supports. From Fig. 3, the m-phase $\mathrm{ZrO}_{2}$ can be confirmed for both of them (JCPDS
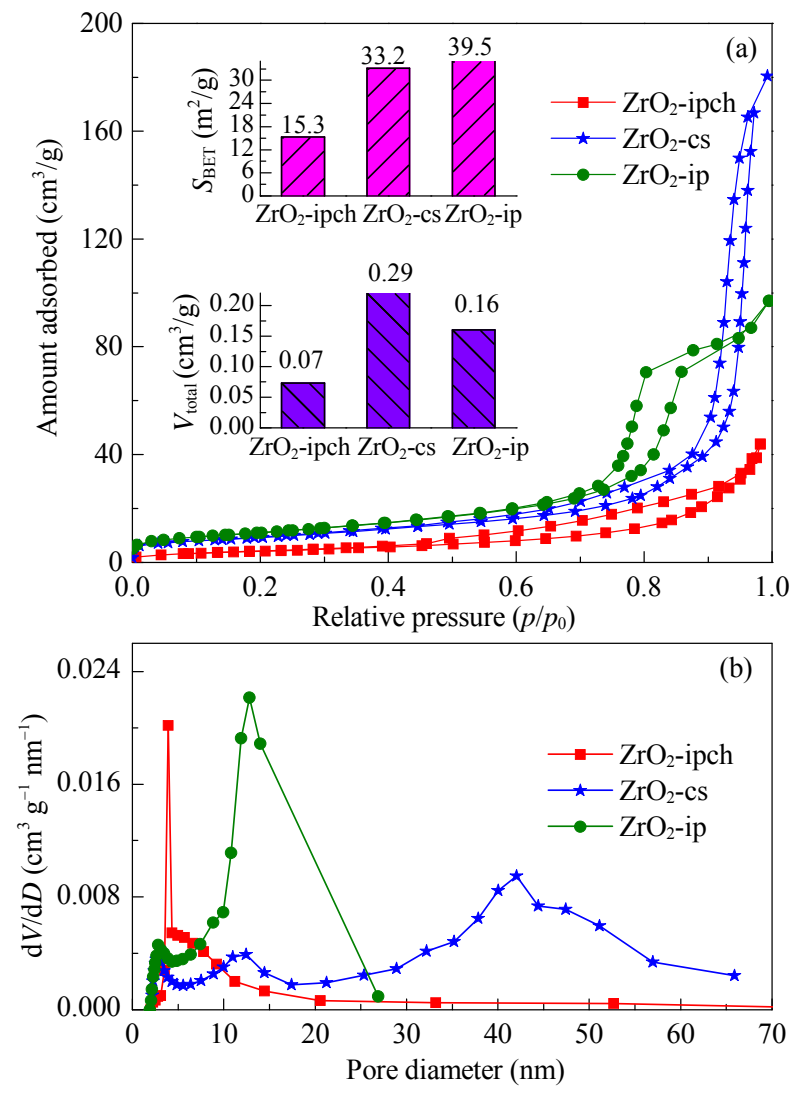

Fig. 2. Nitrogen adsorption isotherms (a) and $\mathrm{BJH}$ pore size distribution from adsorption branch (b) of the $\mathrm{ZrO}_{2}$-ipch, $\mathrm{ZrO}_{2}$-cs and $\mathrm{ZrO}_{2}$-ip supports. Insets: specific surface area and total pore volume. 
Table 1

Physicochemical properties of the $\mathrm{ZrO}_{2}$-ipch, $\mathrm{ZrO}_{2}$-cs and $\mathrm{ZrO}_{2}$-ip supports.

\begin{tabular}{lccc}
\hline Support & \multicolumn{2}{c}{ Average crystalline size ${ }^{\mathrm{a}}(\mathrm{nm})$} & \multirow{2}{*}{$\begin{array}{c}\text { Pore diameter } \\
(\mathrm{nm})\end{array}$} \\
\cline { 2 - 3 } & $550{ }^{\circ} \mathrm{C}$ & $850{ }^{\circ} \mathrm{C}$ & 4.0 \\
$\mathrm{ZrO}_{2}$-ipch & 13.6 & 17.2 & $12.4,42.0$ \\
$\mathrm{ZrO}_{2}$-cs & 12.1 & 21.9 & 12.8 \\
$\mathrm{ZrO}_{2}$-ip & 14.0 & 16.8 & \\
\hline
\end{tabular}

a Comparison of average crystallite sizes of the synthesized $\mathrm{ZrO}_{2}$ from calcination at 550 and $850{ }^{\circ} \mathrm{C}$, estimated by the Scherrer equation from the $\mathrm{m}-\mathrm{ZrO}_{2}(11 \overline{1})$ and (111) planes.

37-1484) [57]. The $\mathrm{ZrO}_{2}$-ipch demonstrated a higher intensity of the XRD peaks than $\mathrm{ZrO}_{2}$-cs, indicating higher crystallinity. The weaker and broader XRD peaks for $\mathrm{ZrO}_{2}$-cs than those for $\mathrm{ZrO}_{2}$-ipch suggest a smaller average crystalline size. The narrowest XRD peaks were observed with $\mathrm{ZrO}_{2}$-ip, indicating the largest average crystallite size. The average crystalline sizes of $\mathrm{m}-\mathrm{ZrO}_{2}$ for the two supports were estimated by the Scherrer equation from the peaks for the (111) and (111) planes of monoclinic $\mathrm{ZrO}_{2}$ (Table 1). The average crystalline size of $\mathrm{m}-\mathrm{ZrO}_{2}$ for the $\mathrm{ZrO}_{2}$-ipch support $(13.6 \mathrm{~nm})$ is larger than that for the $\mathrm{ZrO}_{2}$-cs support (12.1 nm). However, these two crystallite sizes were smaller than that of $\mathrm{ZrO}_{2}$-ip $(14.0 \mathrm{~nm}$ ). A high thermal stability is indispensable for the catalyst support to satisfy the requirement imposed by the harsh conditions for the DRM reaction. Therefore, we compared the thermal stability of the two $\mathrm{ZrO}_{2}$ supports by performing an XRD analysis on the $\mathrm{ZrO}_{2}$ supports after calcinating at $850{ }^{\circ} \mathrm{C}$. The

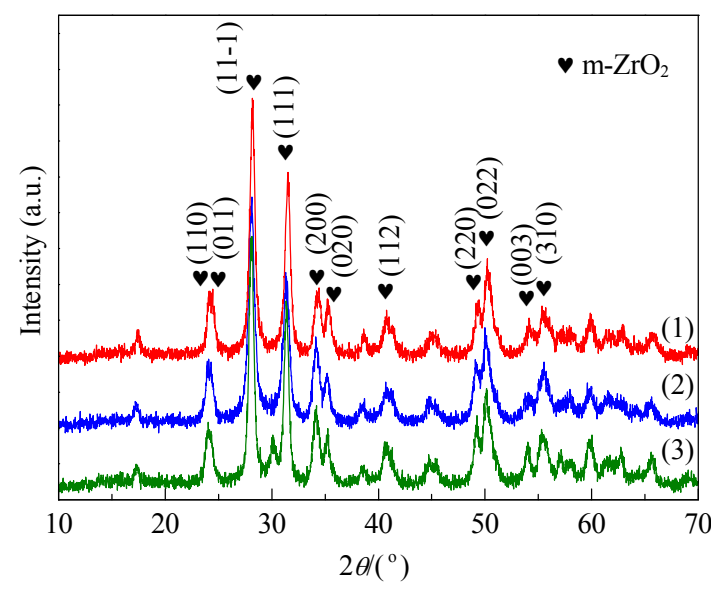

Fig. 3. $\mathrm{XRD}$ patterns of $\mathrm{ZrO}_{2}$-ipch (1), $\mathrm{ZrO}_{2}$-cs (2) and $\mathrm{ZrO}_{2}$-ip (3) supports.

estimated average crystalline sizes of the $\mathrm{m}-\mathrm{ZrO}_{2}$ for the two supports calcined at $850{ }^{\circ} \mathrm{C}$ are listed in Table 1. From Table 1, the crystalline size of $\mathrm{m}-\mathrm{ZrO}_{2}$ for $\mathrm{ZrO}_{2}$-cs increased from 12.1 to $21.9 \mathrm{~nm}(81.0 \%$ growth, the percentage of the increased size over the original size), suggesting its poor thermal stability. However, only $26.5 \%$ growth (from 13.6 to $17.2 \mathrm{~nm}$ ) for the $\mathrm{ZrO}_{2}$-ipch support and $20.0 \%$ of growth (from 14.0 to $16.8 \mathrm{~nm}$ ) for $\mathrm{ZrO}_{2}$-cs were observed. This revealed that both $\mathrm{ZrO}_{2}$-ipch and $\mathrm{ZrO}_{2}$-ip have superior thermal stability in comparison to the $\mathrm{ZrO}_{2}$-cs sample.
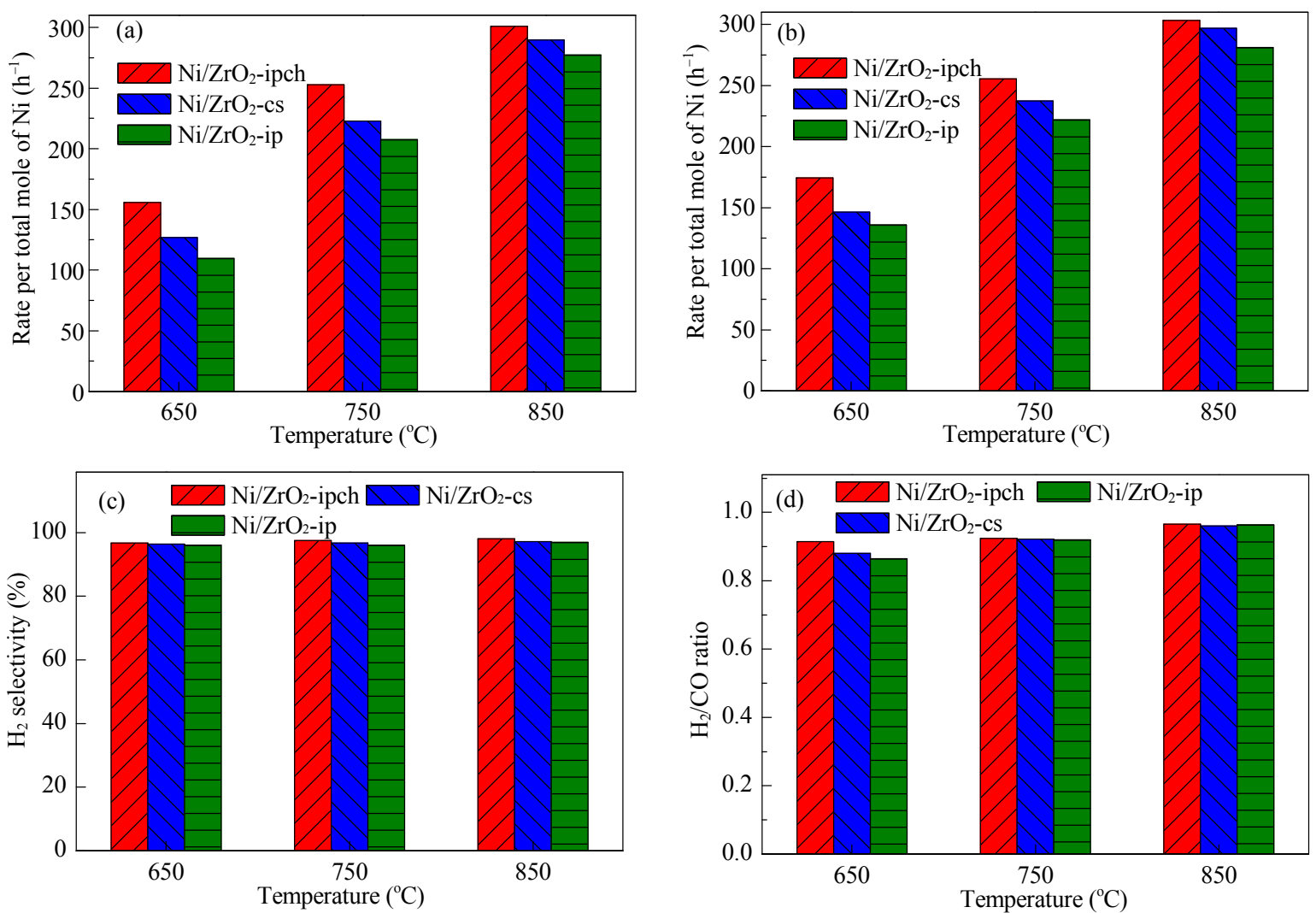

Fig. 4. $\mathrm{CH}_{4}$ rate (a), $\mathrm{CO}_{2}$ rate (b), $\mathrm{H}_{2}$ selectivity (c) and $\mathrm{H}_{2} / \mathrm{CO}$ ratio (d) at different temperatures for $\mathrm{DRM}$ over $\mathrm{Ni} / \mathrm{ZrO} \mathrm{C}_{2}$-ipch, $\mathrm{Ni} / \mathrm{ZrO} \mathrm{C}_{2}$-Cs and $\mathrm{Ni} / \mathrm{ZrO}_{2}$-ip catalysts. Reaction conditions: $m_{\text {cat }}=50 \mathrm{mg}, \mathrm{CH}_{4} / \mathrm{CO}_{2} / \mathrm{N}_{2}=1: 1: 3, \mathrm{GHSV}=60000 \mathrm{~mL} \mathrm{~h}^{-1} \mathrm{~g}^{-1}$, and atmospheric pressure. 


\subsection{Morphology effect of the $\mathrm{ZrO}_{2}$ support on the supported $\mathrm{Ni}$ catalysts for DRM reaction}

The initial catalytic performance evaluation of $\mathrm{Ni} / \mathrm{ZrO}_{2}$-ipch, $\mathrm{ZrO}_{2}$-cs and $\mathrm{Ni} / \mathrm{ZrO}_{2}$-ip catalysts was performed to explore the effect of the morphology of the support (Fig. 4). From Fig. $4(\mathrm{a}, \mathrm{b})$, it can be observed that the $\mathrm{CH}_{4}$ and $\mathrm{CO}_{2}$ rates of all the supported $\mathrm{Ni}$ catalysts were strongly dependent on the reaction temperature, indicating the thermodynamic control of the DRM. The order of the $\mathrm{CH}_{4}$ and $\mathrm{CO}_{2}$ rates was $\mathrm{Ni} / \mathrm{ZrO}_{2}$-ipch $>\mathrm{Ni} / \mathrm{ZrO}_{2}$-cs $>\mathrm{Ni} / \mathrm{ZrO}_{2}$-ip. Moreover, it can be observed that the $\mathrm{CO}_{2}$ rate was higher than $\mathrm{CH}_{4}$ rate over the catalysts, especially at lower reaction temperatures, which might be due to the simultaneous occurrence of the reverse water gas shift (RWGS) reaction [58]. The RWGS reaction results in the $\mathrm{H}_{2} / \mathrm{CO}$ ratio being less than 1 (Fig. 4(d)). From Fig. 4(c,d), an increasing reaction temperature does not result in a visible change in $\mathrm{H}_{2}$ selectvity, but led to an increase in the $\mathrm{H}_{2} / \mathrm{CO}$ ratio, which might be attributed to an enhanced water gas shift (WGS) reaction by the increased temperature.

Table 2 shows that the $\mathrm{Ni} / \mathrm{ZrO}_{2}$-ipch catalyst has a lower surface area $\left(17 \mathrm{~m}^{2} / \mathrm{g}\right)$ than $\mathrm{Ni} / \mathrm{ZrO}_{2}$-cs $\left(20 \mathrm{~m}^{2} / \mathrm{g}\right)$ and $\mathrm{Ni} / \mathrm{ZrO}_{2}$-ip $\left(32 \mathrm{~m}^{2} / \mathrm{g}\right)$. Generally, supported $\mathrm{Ni}$ catalysts show a lower surface area than their corresponding support. Interestingly, the $\mathrm{Ni} / \mathrm{ZrO}_{2}$-ipch catalyst showed a higher specific surface area than the $\mathrm{ZrO}_{2}$-ipch support $\left(15.3 \mathrm{~m}^{2} / \mathrm{g}\right)$, which was ascribed to a high Ni dispersion and higher thermal stability of the $\mathrm{ZrO}_{2}$-ipch support (Table 1). On correlating the surface area data to reaction results, in comparison with $\mathrm{Ni} / \mathrm{ZrO}_{2}$-cs or $\mathrm{Ni} / \mathrm{ZrO}_{2}$-ip, the lower surface area of the $\mathrm{Ni} / \mathrm{ZrO}_{2}$-ipch catalyst did not reduce the rate for $\mathrm{CH}_{4}$ and $\mathrm{CO}_{2}$ transformation, implying that there were other aspects that resulted in its higher catalytic activity. Therefore, XRD, CO chemisorption, $\mathrm{H}_{2}$-TPR, $\mathrm{CO}_{2}$-TPD and XPS experiments were further performed to reveal the origin for the higher catalytic activity of the $\mathrm{Ni} / \mathrm{ZrO}_{2}$-ipch catalyst in comparison with $\mathrm{Ni} / \mathrm{ZrO}_{2}$-cs or $\mathrm{Ni} / \mathrm{ZrO}_{2}$-ip for the DRM reaction.

Fig. 5 presents the XRD patterns of the $\mathrm{Ni} / \mathrm{ZrO}_{2}$-ipch, $\mathrm{Ni} / \mathrm{ZrO}_{2}$-cs and $\mathrm{Ni} / \mathrm{ZrO}_{2}$-ip catalysts. In Fig. 5 , the XRD peaks appearing at $44.5^{\circ}, 51.8^{\circ}$ and $76.4^{\circ}$ can be well resolved, and were assigned to the reflections of the (111), (200) and (220) planes of the face centered cubic (fcc) Ni phase (JCPDS No. 65-2865), respectively. The weaker and broader XRD peaks corresponding to the (111), (200) and (220) planes of $\mathrm{Ni}$ for the $\mathrm{Ni} / \mathrm{ZrO}_{2}$-ipch catalyst in comparison with those for $\mathrm{Ni} / \mathrm{ZrO}_{2}$-cs or $\mathrm{Ni} / \mathrm{ZrO}_{2}$-ip can be clearly seen, which suggested a better dispersion of $\mathrm{Ni}$ on $\mathrm{ZrO}_{2}$-ipch. The average crystalline

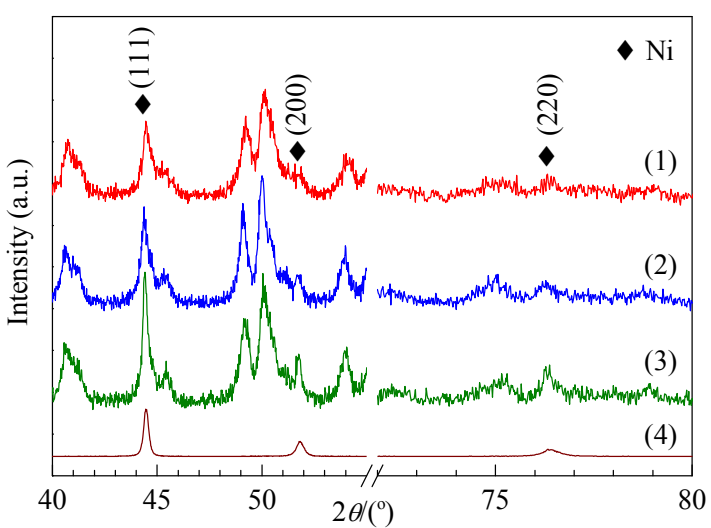

Fig. 5. XRD patterns of $\mathrm{Ni} / \mathrm{ZrO}_{2}$-ipch (1), $\mathrm{Ni} / \mathrm{ZrO}_{2}$-cs (2) and $\mathrm{Ni} / \mathrm{ZrO}_{2}$-ip (3) catalysts, and bulk $\mathrm{Ni}$ (4) included for reference.

size of Ni for the two catalysts was estimated by the Scherrer equation based on the above three typical reflections planes. The results are listed in Table 2. From Table 2, the 12.7, 13.3 and $20.4 \mathrm{~nm}$ of the average crystalline size of $\mathrm{Ni}$ for $\mathrm{Ni} / \mathrm{ZrO}_{2}$-ipch, $\mathrm{Ni} / \mathrm{ZrO}_{2}$-cs and $\mathrm{Ni} / \mathrm{ZrO}_{2}$-ip, respectively, can be seen. The smaller average crystalline size of $\mathrm{Ni}$ for $\mathrm{Ni} / \mathrm{ZrO}_{2}$-ipch may be one reason for its higher catalytic acivity for DRM in comparison with $\mathrm{Ni} / \mathrm{ZrO}_{2}$-cs or $\mathrm{Ni} / \mathrm{ZrO}_{2}$-ip catalyst. $\mathrm{CO}$ chemisorption was performed to measure the $\mathrm{Ni}$ dispersion. The chemisorption stoichimetry of $\mathrm{CO}$ to $\mathrm{Ni}$ was assumed to be 1 [52]. The results are listed in Table 2. The higher $\mathrm{Ni}$ dispersion $(5.3 \%)$ of the $\mathrm{Ni} / \mathrm{ZrO}_{2}$-ipch catalyst than that of $\mathrm{Ni} / \mathrm{ZrO}_{2}$-cs $(3.8 \%)$ and $\mathrm{Ni} / \mathrm{ZrO}_{2}$-ip (3.1\%) can be observed, revealing the effect of the morphology of the support on $\mathrm{Ni}$ dispersion of a supported $\mathrm{Ni}$ catalyst. The higher Ni dispersion of the $\mathrm{Ni} / \mathrm{ZrO}_{2}$-ipch catalyst endowed it with a higher catalytic activity for the DRM by the increased active sites.

The $\mathrm{H}_{2}$-TPR technique is a powerful tool for unveiling the reducibility and metal-support interaction of supported metal catalysts. Fig. 6 presents the $\mathrm{H}_{2}$-TPR profiles for the $\mathrm{Ni} / \mathrm{ZrO}_{2}$-ipch, $\mathrm{Ni} / \mathrm{ZrO}_{2}$-cs and $\mathrm{Ni} / \mathrm{ZrO}_{2}$-ip catalysts. The quantitative analytical results are listed in Table 2. In Fig. 6, the $\mathrm{H}_{2}$-TPR profiles for the two catalysts can be roughly divided into two reduction regions (region I and region II). Region I can be assigned to the reduction of free $\mathrm{NiO}$ on the support surface and the reduction of $\mathrm{NiO}$ with a weak metal-support interaction [59-61], whereas region II can be assigned to the reduction of $\mathrm{NiO}$ with a strong $\mathrm{Ni}-\mathrm{ZrO}_{2}$ interaction [52]. The initial reduction temperature for region I corresponding to the $\mathrm{Ni} / \mathrm{ZrO}_{2}$-ipch catalyst was shifted to a lower temperature, which might be ascribed to the reduction of surface oxygen species. From Table

Table 2

Characteristics of the $\mathrm{Ni} / \mathrm{ZrO}_{2}$-ipch, $\mathrm{Ni} / \mathrm{ZrO}_{2}$-cs and $\mathrm{Ni} / \mathrm{ZrO}_{2}$-ip catalysts.

\begin{tabular}{|c|c|c|c|c|c|c|c|c|c|}
\hline \multirow{2}{*}{ Catalyst } & \multirow{2}{*}{$\begin{array}{c}S_{\text {BET }} \\
\left(\mathrm{m}^{2} / \mathrm{g}\right)\end{array}$} & \multicolumn{2}{|c|}{$\mathrm{CS}_{\mathrm{Ni}}{ }^{\mathrm{a}}(\mathrm{nm})$} & \multirow{2}{*}{$\begin{array}{l}D_{\mathrm{Ni}} \mathrm{b} \\
(\%)\end{array}$} & \multicolumn{2}{|c|}{$\mathrm{H}_{2}$ uptake ${ }^{\mathrm{c}}(\mathrm{mmol} / \mathrm{g})$} & \multirow{2}{*}{$\begin{array}{c}\text { Reduction degree } \\
(\%)\end{array}$} & \multirow{2}{*}{$\begin{array}{c}\mathrm{CO}_{2} \text { desorption } \\
(\mu \mathrm{mol} / \mathrm{g})\end{array}$} & \multirow{2}{*}{$\begin{array}{c}\text { Coke rate } \\
\left(\mathrm{mg} \mathrm{g}_{\text {cat }}{ }^{-1} \mathrm{~h}^{-1}\right)\end{array}$} \\
\hline & & Fresh & Spent & & I & II & & & \\
\hline $\mathrm{Ni} / \mathrm{ZrO}_{2}$-ipch & 17 & 12.7 & 13.0 & 5.3 & 0.52 & 0.52 & 38.1 & 64.6 & 1.95 \\
\hline $\mathrm{Ni} / \mathrm{ZrO}_{2}-\mathrm{cs}$ & 20 & 13.3 & - & 3.8 & 0.75 & 0.21 & 35.8 & 57.2 & - \\
\hline $\mathrm{Ni} / \mathrm{ZrO}_{2}$-ip & 32 & 20.4 & 25.5 & 3.1 & 0.84 & - & 31.6 & 36.7 & 6.19 \\
\hline
\end{tabular}

a Average crystalline size of $\mathrm{Ni}$ for fresh and spent catalysts was estimated by the Scherrer equation based on the $\mathrm{Ni}(111) \mathrm{plane}$.

b Determined by CO chemisorption.

c Measured by $\mathrm{H}_{2}$-TPR experiments. 


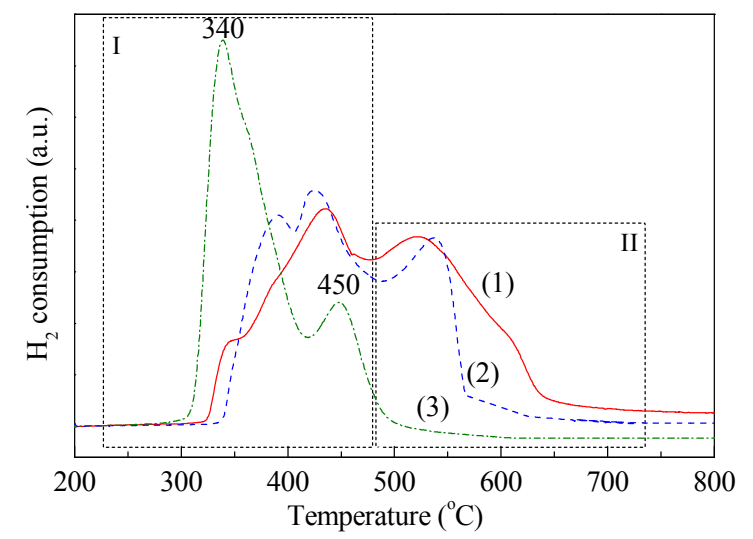

Fig. 6. $\mathrm{H}_{2}$-TPR profiles of the $\mathrm{NiO} / \mathrm{ZrO}_{2}$-ipch (1), $\mathrm{NiO} / \mathrm{ZrO}_{2}$-cs (2) and $\mathrm{NiO} / \mathrm{ZrO}_{2}$-ip (3) samples.

2, the $\mathrm{H}_{2}$ uptake for region II of the $\mathrm{Ni} / \mathrm{ZrO}_{2}$-ipch catalyst was much higher than that of the $\mathrm{Ni} / \mathrm{ZrO}_{2}$-cs catalyst, indicating more NiO with a strong metal-support interaction. Interestingly, no peak in region II from $\mathrm{Ni} / \mathrm{ZrO}_{2}$-ip was observed, suggesting the weakest Ni-support interaction. A strong $\mathrm{Ni}-\mathrm{ZrO}_{2}$ interaction is favorable for high $\mathrm{Ni}$ sintering resistance, which would improve the catalytic stability for DRM at high temperature. Moreover, from Table 2, the $\mathrm{Ni} / \mathrm{ZrO}_{2}$-ipch catalyst exhibited a higher reduction degree (the percentage of total $\mathrm{H}_{2}$ consumption to the nominal $\mathrm{H}_{2}$ uptake for $\mathrm{NiO}$ complete reduction, $38.1 \%$ ) in comparison with that of the $\mathrm{Ni} / \mathrm{ZrO}_{2}$-cs (35.8\%) and $\mathrm{Ni} / \mathrm{ZrO}_{2}$-ip (31.6\%) catalysts, which allowed the $\mathrm{Ni} / \mathrm{ZrO}_{2}$-ipch catalyst to exhibit superior catalytic activity to the other two catalysts.

$\mathrm{CO}_{2}$-TPD was conducted to investigate the surface basic properties of the catalysts, which signifiantly affects the adsorption and activation of $\mathrm{CO}_{2}$ [62-64]. Fig. 7 presents the $\mathrm{CO}_{2}$-TPD profiles, and the quantitative results are listed in Table 2. In Fig. 7, besides the desorption peak at $129{ }^{\circ} \mathrm{C}$ (weak basic sites) in the $\mathrm{CO}_{2}$-TPD profile of the $\mathrm{Ni} / \mathrm{ZrO}_{2}$-ipch catalyst, another peak at $247^{\circ} \mathrm{C}$ can be clearly observed. However, only one peak occurred at $112{ }^{\circ} \mathrm{C}$ in the $\mathrm{CO}_{2}$-TPD profile of $\mathrm{Ni} / \mathrm{ZrO}_{2}$-cs and at $113{ }^{\circ} \mathrm{C}$ in the $\mathrm{CO}_{2}$-TPD profile of the $\mathrm{Ni} / \mathrm{ZrO}_{2}$-ip catalyst. This result illustrated that the $\mathrm{Ni} / \mathrm{ZrO}_{2}$-ipch catalyst has strong basic sites in addition to the existing weak

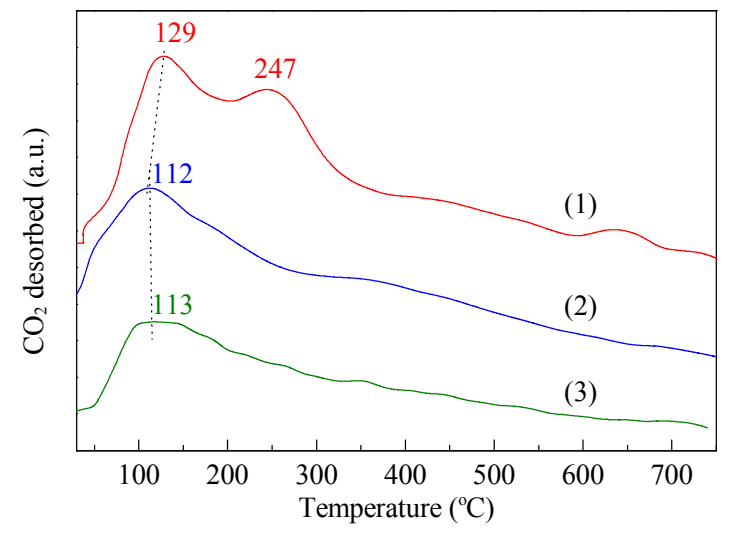

Fig. 7. $\mathrm{CO}_{2}$-TPD profiles of the $\mathrm{Ni} / \mathrm{ZrO}_{2}$-ipch (1), Ni/ZrO $\mathrm{Ni} / \mathrm{ZrO}_{2}$-ip (3) catalysts.

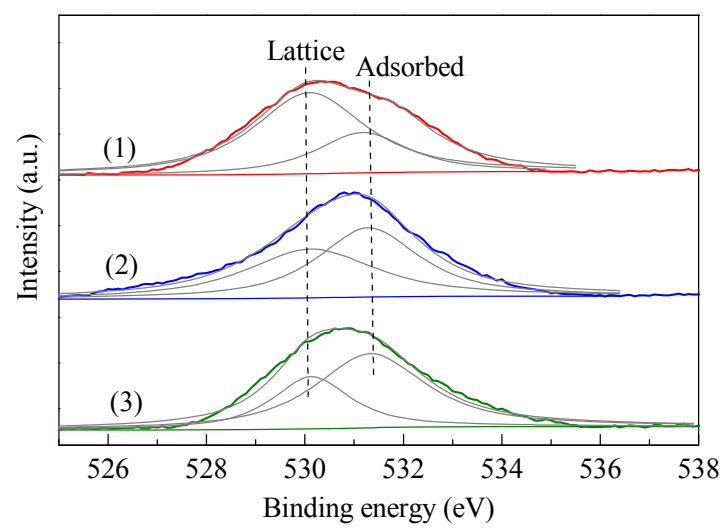

Fig. 8. $01 s$ region of the XPS spectra for the $\mathrm{Ni} / \mathrm{ZrO}_{2}$-ipch (1), $\mathrm{Ni} / \mathrm{ZrO}_{2}$-cs (2) and $\mathrm{Ni} / \mathrm{ZrO}_{2}$-ip (3) catalysts.

ones. From Table 2, the total desorbed $\mathrm{CO}_{2}$ from the $\mathrm{Ni} / \mathrm{ZrO}_{2}$-ipch catalyst $(64.6 \mu \mathrm{mol} / \mathrm{g})$ was more than that of the $\mathrm{Ni} / \mathrm{ZrO}_{2}$-cs $(57.2 \mu \mathrm{mol} / \mathrm{g})$ and $\mathrm{Ni} / \mathrm{ZrO}_{2}$-ip catalysts (36.7 $\mu \mathrm{mol} / \mathrm{g}$ ). In comparison with the $\mathrm{Ni} / \mathrm{ZrO}_{2}$-cs catalyst, more and stronger basic sites can promote the adsorption and activation of $\mathrm{CO}_{2}$, which can efficiently enhance the DRM reaction. From the references $[65,66]$, lattice oxygen $\left(\mathrm{O}^{2}\right)$ can activate the $\mathrm{C}-\mathrm{H}$ bond and also promote coke gasification.

The surface oxygen species were monitored by XPS analysis. Fig. 8 displays the $01 s$ region of the XPS spectra for the $\mathrm{Ni} / \mathrm{ZrO}_{2}$-ipch, $\mathrm{Ni} / \mathrm{ZrO}_{2}$-cs and $\mathrm{Ni} / \mathrm{ZrO}_{2}$-ip catalysts. In Fig. 8, the $01 \mathrm{~s}$ spectra of the two catalysts can be deconvoluted into two peaks. The peaks at 530.1 and $531.4 \mathrm{eV}$ can be assigned to lattice oxygen $\left(\mathrm{O}^{2-}\right)$ and adsorbed oxygen, respectively [55,56]. The percentage of lattice oxygen and adsorbed oxygen to the total amount of $\mathrm{O}, \mathrm{Ni}$, and $\mathrm{Zr}$ is summarized in Table 3 . It can be observed that the percentage of the lattice oxygen on $\mathrm{Ni} / \mathrm{ZrO}_{2}$-ipch $(49.7 \%)$ was much higher than that on the $\mathrm{Ni} / \mathrm{ZrO}_{2}$-cs $(30.7 \%)$ and $\mathrm{Ni} / \mathrm{ZrO}_{2}$-ip (23.4\%) catalysts. The higher percentage of lattice oxygen allows $\mathrm{Ni} / \mathrm{ZrO}_{2}$-ipch to exhibit higher catalytic activity and coke resistant stability $[65,66]$.

\subsection{Morphology effect of the $\mathrm{ZrO}_{2}$ support on the longterm stability of supported Ni catalysts}

Deactivation by coke is still the key problem to be solved for the industrial application of Ni-based catalysts for the DRM reaction. Therefore, the development of stable and coke resistant catalysts is a major concern. Here, the morphology effect of the support on the catalytic stability of the supported Ni catalysts for the DRM reaction was investigated. The results are

Table 3

XPS data for the $\mathrm{Ni} / \mathrm{ZrO}_{2}$-ipch, $\mathrm{Ni} / \mathrm{ZrO}_{2}$-cs and $\mathrm{Ni} / \mathrm{ZrO}_{2}$-ip catalysts ${ }^{\mathrm{a}}$.

\begin{tabular}{lccccc}
\hline \multirow{2}{*}{ Catalyst } & \multicolumn{2}{c}{ Lattice oxygen } & & \multicolumn{2}{c}{ Adsorbed oxygen } \\
\cline { 2 - 3 } \cline { 5 - 6 } & \multicolumn{1}{c}{$\mathrm{BE}(\mathrm{eV})$} & Percentage $(\%)$ & & BE $(\mathrm{eV})$ & Percentage (\%) \\
\hline $\mathrm{Ni} / \mathrm{ZrO}_{2}$-ipch & 530.0 & 49.7 & & 531.4 & 20.2 \\
$\mathrm{Ni} / \mathrm{ZrO}_{2}$-cs & 530.1 & 30.7 & & 531.4 & 33.9 \\
$\mathrm{Ni} / \mathrm{ZrO}_{2}$-ip & 530.1 & 23.4 & & 531.4 & 45.1 \\
\hline
\end{tabular}

a The atom percentage of $\mathrm{O}$ atom to total amount of $\mathrm{O}, \mathrm{Ni}$, and $\mathrm{Zr}$ from XPS analysis. 

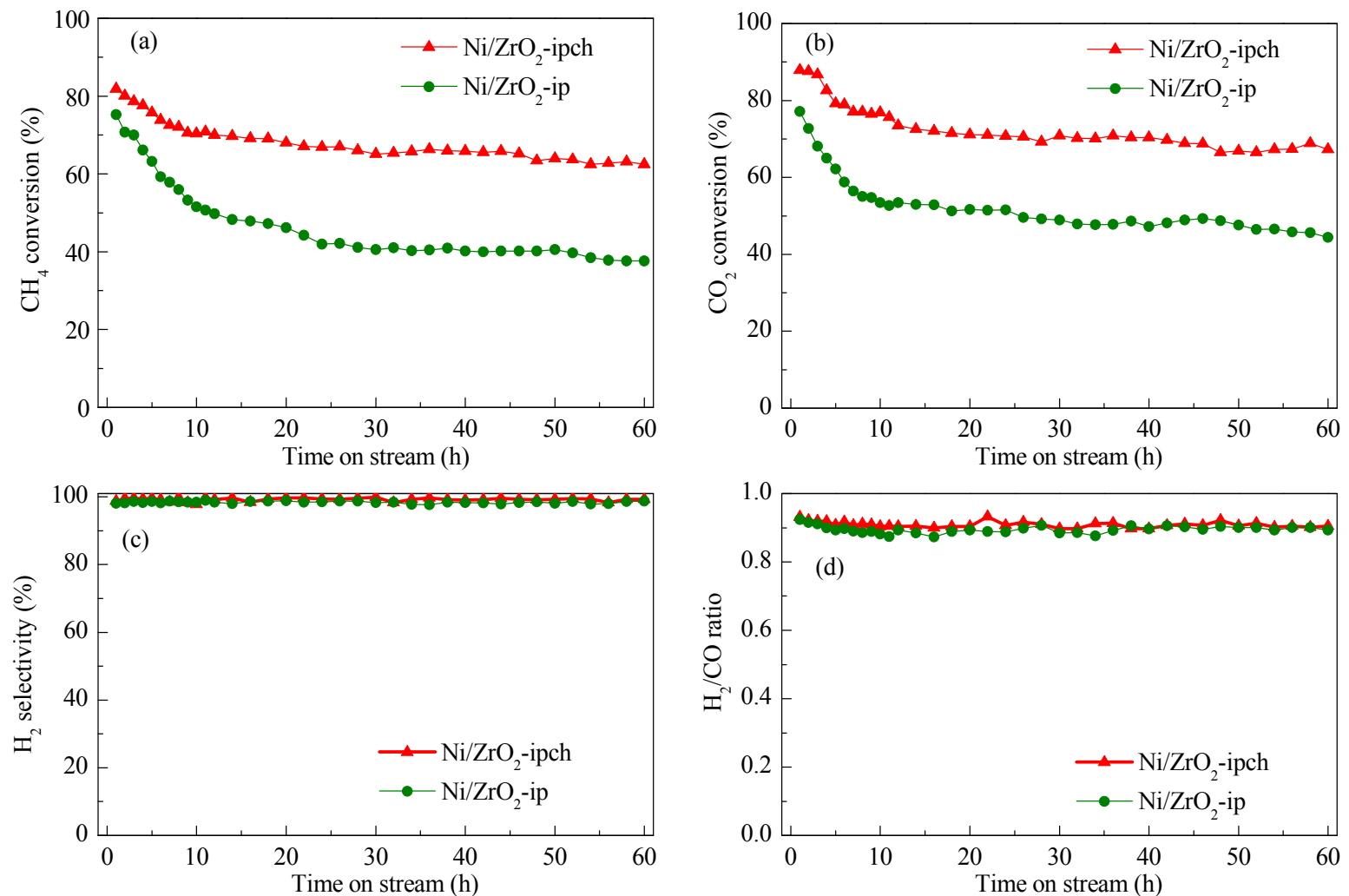

Fig. 9. $\mathrm{CH}_{4}$ conversion (a), $\mathrm{CO}_{2}$ conversion (b), $\mathrm{H}_{2}$ selectivity (c) and $\mathrm{H}_{2} / \mathrm{CO}$ ratio (d) as a function of time on stream for $\mathrm{CO}_{2}$ dry reforming of methane over the $\mathrm{Ni} / \mathrm{ZrO}_{2}$-ipch and $\mathrm{Ni} / \mathrm{ZrO}_{2}$-ip catalysts. Reaction conditions: $m_{\text {cat }}=30 \mathrm{mg}, \mathrm{CH}_{4}: \mathrm{CO}_{2}: \mathrm{N}_{2}=1: 1: 3, \mathrm{GHSV}=100000 \mathrm{~mL} \mathrm{~h}^{-1} \mathrm{~g}^{-1}, T=850{ }^{\circ} \mathrm{C}$, atmospheric pressure.

displayed in Fig. 9. From Fig. 9, the $\mathrm{Ni} / \mathrm{ZrO}_{2}$-ipch catalyst exhibited higher catalytic activity and stability in comparison with the $\mathrm{Ni} / \mathrm{ZrO}_{2}$-ip catalyst during $30 \mathrm{~h}$ of time on stream reaction. From the above analysis, a higher activity of the $\mathrm{Ni} / \mathrm{ZrO}_{2}$-ipch catalyst in comparison with $\mathrm{Ni} / \mathrm{ZrO}_{2}$-ip can be ascribed to the higher Ni dispersion, reducibility, percentage of lattice oxygen, and more basic sites with higher strength. From Fig. $9(\mathrm{c}, \mathrm{d})$, the two catalysts have similar $\mathrm{H}_{2}$ selectivity and $\mathrm{H}_{2} / \mathrm{CO}$ ratio. The $\mathrm{Ni} / \mathrm{ZrO}_{2}$-ipch catalyst exhibited outstanding catalytic stability including the converison of $\mathrm{CH}_{4}$ and $\mathrm{CO}_{2}, \mathrm{H}_{2}$ selectivity and $\mathrm{H}_{2} / \mathrm{CO}$ for DRM reaction, which makes it a promosing catalyst for synthesis gas production through the DRM reaction.

The XRD, TEM and TGA techniques were used to unveil the reason for the outstanding catalytic stability of the $\mathrm{Ni} / \mathrm{ZrO}_{2}$-ipch catalyst. Fig. 10 displays the XRD patterns of the fresh and spent $\mathrm{Ni} / \mathrm{ZrO}_{2}$-ipch and $\mathrm{Ni} / \mathrm{ZrO}_{2}$-ip catalysts. The average crystalline size of $\mathrm{Ni}$ was estimated by the Scherrer equation on the basis of the Ni (111), (200) and (220) planes (Table 2). From Fig. 10 and Table 2, no visible Ni sintering on the two catalysts can be observed, suggesting the existence of a strong $\mathrm{Ni}-\mathrm{ZrO}_{2}$ interaction on the two catalysts. In addition, compared with the fresh catalysts, the spent $\mathrm{Ni} / \mathrm{ZrO}_{2}$-ipch and $\mathrm{Ni} / \mathrm{ZrO}_{2}$-ip catalysts show an obvious diffraction peak ascribed to graphitic carbon located at $26^{\circ}$ [67]. The stronger diffraction peak corresponding to graphitic carbon from $\mathrm{Ni} / \mathrm{ZrO}_{2}$-ip than from $\mathrm{Ni} / \mathrm{ZrO}_{2}$-ipch can be observed. Therefore, it can be proposed that the poorer stability of $\mathrm{Ni} / \mathrm{ZrO}_{2}$-ip should be ascribed to its weaker coke resistance. TEM and TGA measurements were performed to further investigate the coking behavior of the two catalysts.

Fig. 11 displays typical TEM images of the two spent catalysts. In Fig. 11, coke with a nano-tubular feature on the two catalysts can be observed. Moreover, the amount of this kind of tubular carbon on the spent $\mathrm{Ni} / \mathrm{ZrO}_{2}$-ip catalyst was much more than that on the $\mathrm{Ni} / \mathrm{ZrO}_{2}$-ipch catalyst. The amount of

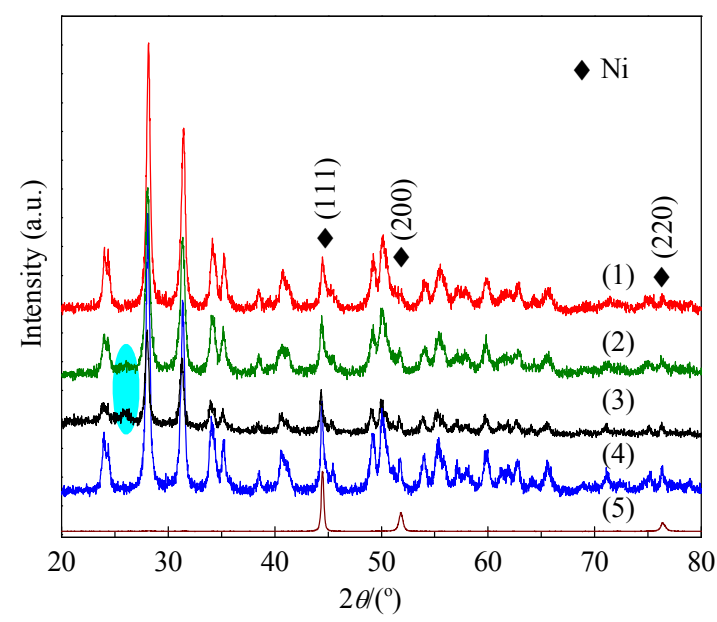

Fig. 10. XRD patterns of fresh and spent supported $\mathrm{Ni}$ catalysts (Ni/ZrO $\mathrm{Zr}_{2}$-ipch and $\mathrm{Ni} / \mathrm{ZrO}_{2}$-ip) and bulk $\mathrm{Ni}$ included for reference. (1) $\mathrm{Ni} / \mathrm{ZrO}_{2}$-ipch (fresh); (2) $\mathrm{Ni} / \mathrm{ZrO}_{2}$-ipch (spent); (3) $\mathrm{Ni} / \mathrm{ZrO}_{2}$-ip (spent); (4) $\mathrm{Ni} / \mathrm{ZrO}_{2}$-ip (fresh); (5) metallic $\mathrm{Ni}$. 


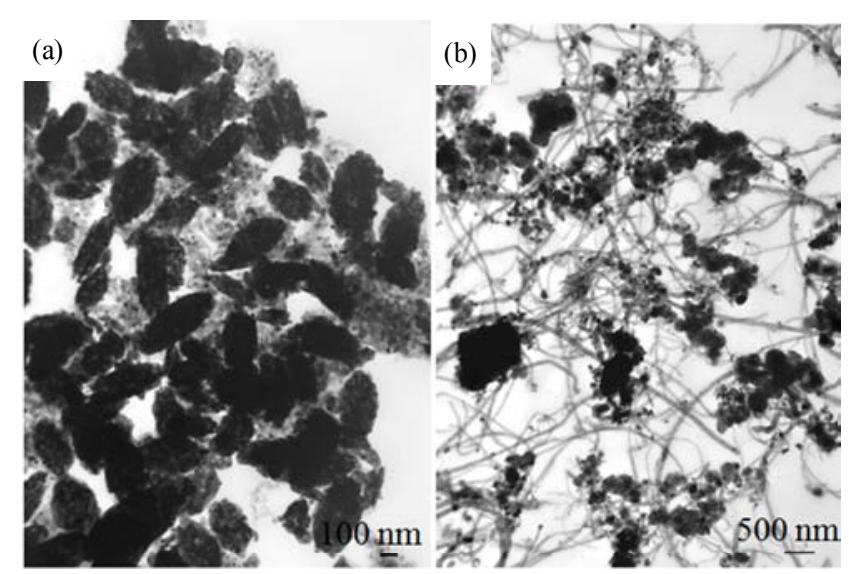

Fig. 11. TEM images of spent $\mathrm{Ni} / \mathrm{ZrO}_{2}$-ipch (a) and $\mathrm{Ni} / \mathrm{ZrO}_{2}$-ip (b) catalysts.

deposited coke on the two spent catalysts was further investigated by TGA analysis.

Fig. 12 presents the TGA/DTG curves of the spent $\mathrm{Ni} / \mathrm{ZrO}_{2}$-ipch and $\mathrm{Ni} / \mathrm{ZrO}_{2}$-ip catalysts. The coking rate calculated on the basis of the TGA analysis is summarized in Table 2. From Fig. 12 and Table 2, the $\mathrm{Ni} / \mathrm{ZrO}_{2}$-ipch demonstrated a lower mass loss (9.0 wt\%) and coking rate (1.95 $\left.\mathrm{mg} \mathrm{g}^{-1} \mathrm{~h}^{-1}\right)$ than the $\mathrm{Ni} / \mathrm{ZrO}_{2}$-ip catalyst $\left(35.1 \%, 6.19 \mathrm{mg} \mathrm{g}^{-1} \mathrm{~h}^{-1}\right)$. In comparison with the previously reported $\mathrm{Ni} / \mathrm{ZrO}_{2}-\mathrm{AN}$ catalyst, the developed supported $\mathrm{Ni}$ catalyst on $\mathrm{ZrO}_{2}$ exhibited
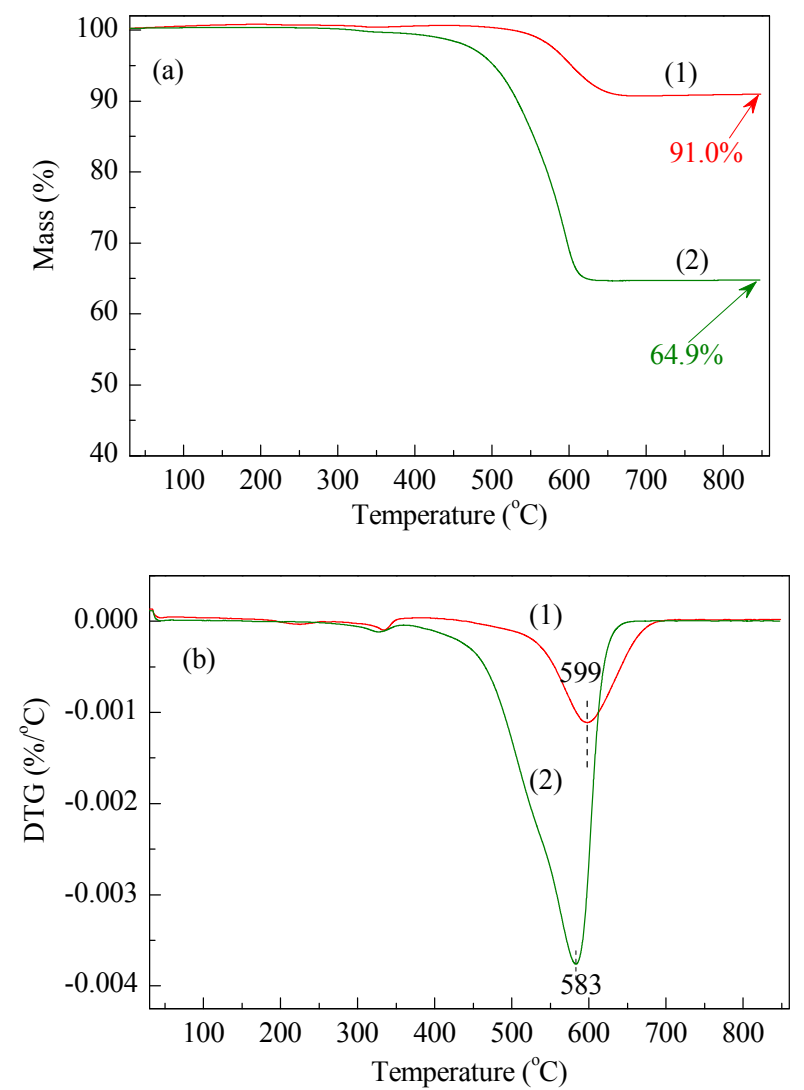

Fig. 12. TGA (a) and DTG (b) curves for the spent $\mathrm{Ni} / \mathrm{ZrO}_{2}$-ipch (1) and $\mathrm{Ni} / \mathrm{ZrO}_{2}$-ip (2) catalysts. obviously better coking resistance [43]. Even if when comapred with a supported $\mathrm{Ni}$ nanosheet catalyst, $\mathrm{Ni} / \mathrm{ZrO}_{2}$-ipch still exhibited a much lower coke formation rate [68]. According to the litearure [65,69], lattice oxygen can react with deposited carbon on the surface of catalysts, and the residual vacancies can be supplied by $\mathrm{CO}_{2}$. Moreover, the promoted adsorption and activation by the more basic sites of $\mathrm{Ni} / \mathrm{ZrO}_{2}$-ipch catalyst also can eliminate deposited coke [70,71]. Furthermore, from Figs. 1 and 2, one can clearly see that the $\mathrm{ZrO}_{2}$-ipch sample contains mesopores with a narrow pore size distribution in the region of $4 \mathrm{~nm}$, which may endow it with good catalytic stability through the stabilization effect on nickel particles against sintering and coke deposition by the confinement effect of the mesopores [33,69,72,73]. The much smaller crystallite size of $\mathrm{Ni}$ on $\mathrm{Ni} / \mathrm{ZrO}_{2}$-ipch was also one reason for its higher coke tolerance than $\mathrm{Ni} / \mathrm{ZrO}_{2}$-ip [17,62,74-76]. From Fig. 12(b), only one peak in the DTG curves of the two catalysts can be observed, suggesting only one type of coke on the two catalysts. The lower temperature for the DTG peak on $\mathrm{Ni} / \mathrm{ZrO}_{2}$-ipch in comparison with that on $\mathrm{Ni} / \mathrm{ZrO}_{2}$-ip indicated the more active coke species on $\mathrm{Ni} / \mathrm{ZrO}_{2}$-ipch. The more active the coke is, the easier the coke gasification is. This might also be one reason for the higher coke resistant stability of $\mathrm{Ni} / \mathrm{ZrO}_{2}$-ipch during the DRM reaction. Correlating the XPS and $\mathrm{CO}_{2}$-TPD to the TGA results, the more lattice oxygen and surface basic sites on the $\mathrm{Ni} / \mathrm{ZrO}_{2}$-ipch catalyst than those on $\mathrm{Ni} / \mathrm{ZrO}_{2}$-ip significntly improve the coke resistant ability of $\mathrm{Ni} / \mathrm{ZrO}_{2}$-ipch, which endowed $\mathrm{Ni} / \mathrm{ZrO}_{2}$-ipch to be a promising catalyst for synthesis gas production through the DRM reaction.

\section{Conclusions}

An immature pinecone shaped hierarchically structured zirconia $\left(\mathrm{ZrO}_{2}\right.$-ipch), agglomerated porous cobblestone-like zirconia $\left(\mathrm{ZrO}_{2}\right.$-cs) and traditional irregular $\mathrm{ZrO}_{2}$ particles ( $\mathrm{ZrO}_{2}$-ip) as supports were synthesized by a facile hydrothermal method. The hierarchically structured $\mathrm{Ni} / \mathrm{ZrO}_{2}$-ipch catalyst exhibited much higher activity and stability in comparison with $\mathrm{Ni} / \mathrm{ZrO}_{2}$-ip. The catalytic performance was significantly dependent on $\mathrm{Ni}$ crystalline size, $\mathrm{Ni}$ dispersion, reducibility, lattice oxygen percentage, and basic properties, which were notably affected by the morphology of the support. The higher activity and Ni- and coke resistant stability of the $\mathrm{Ni} / \mathrm{ZrO}_{2}$-ipch catalyst makes it a potential candidate for the DRM reaction. Owing to its unique microstructure and high thermal stability, the immature pinecone shaped hierarchically structured zirconia would be a promising support for synthesizing other supported catalysts for diverse transformations, especially for high temperature reactions.

\section{References}

[1] D. Pakhare, J. Spivey, Chem. Soc. Rev., 2014, 43, 7813-7837.

[2] W. Chu, L. N. Wang, P. A. Chernavskii, A. Y. Khodakov, Angew. Chem. Int. Ed., 2008, 47, 5052-5055.

[3] V. M. Gonzalez-Delacruz, R. Pereniguez, F. Ternero, J. P. Holgado, A. Caballero, ACS Catal., 2011, 1, 82-88. 
[4] S. Damyanova, B. Pawelec, K. Arishtirova, M. M. Huerta, J. Fierro, Appl. Catal. B, 2009, 89, 149-159.

[5] A. Yamaguchi, E. Iglesia, J. Catal., 2010, 274, 52-63.

[6] S. H. Zhang, S. Muratsugu, N. Ishiguro, M. Tada, ACS Catal., 2013, 3, 1855-1864.

[7] M. J. Yu, Y. A. Zhu, Y. Lu, G. S. Tong, K. Zhu, X. Q. Zhou, Appl. Catal. B, 2015, 165, 43-56.

[8] A. I. Paksoy, B. S. Caglayan, A. E. Aksoylu, Appl. Catal. B, 2015, 168, 164-174.

[9] F. Barrai, T. Jackson, N. Whitmore, M. J. Castaldi, Catal. Today, 2007, 129, 391-396.

[10] M. S. Fan, A. Z. Abdullah, S. Bhatia, ChemCatChem, 2009, 1, 192-208.

[11] C. Carrara, J. Munera, E. A. Lombardo and L. M. Cornaglia, Top. Catal., 2008, 51, 98-106.

[12] D. P. Liu, W. N. E. Cheo, Y. W. Y. Lim, A. Borgna, R. Lau, Y. Yang, Catal. Today, 2010, 154, 229-236.

[13] Z. Y. Hou, P. Chen, H. F. Fang, X. M. Zheng, T. M. Yashima, Int. J. Hydrogen Energy, 2006, 31, 555-561.

[14] J. S. Zhang, F. X. Li, Appl. Catal. B, 2015, 176, 513-521.

[15] J. W. Han, C. Kim, J. S. Park, H. Lee, ChemSusChem, 2014, 7, 451-456.

[16] S. Das, S. Thakur, A. Bag, M. S. Gupta, P. Mondal, A. Bordoloi, J. Catal., 2015, 330, 46-60.

[17] C. Z. Wang, N. N. Sun, N. Zhao, W. Wei, J. Zhang, T. J. Zhao, Y. H. Sun, C. Q. Sun, H. Liu, C. E. Snape, ChemCatChem, 2014, 6, 640-648.

[18] H. Zhang, M. Li, P. Xiao, D. Liu, C. J. Zou, Chem. Eng. J., 2013, 36, 1701-1707.

[19] A. Serrano-Lotina, L. Daza, Int. J. Hydrogen Energy, 2014, 39, 4089-4094.

[20] A. Serrano-Lotina, L. Daza, Appl. Catal. A, 2014, 474, 107-113.

[21] Y. Kathiraser, U. Oemar, E. T. Saw, Z. Li, S. Kawi, Chem. Eng. J., 2015, 278, 62-78.

[22] I. H. Son, S. Kwon, J. H. Park, S. J. Lee, Nano Energy, 2016, 19, 58-67.

[23] L. P. Qian, Z. Ma, Y. Ren, H. C. Shi, B. Yue, S. J. Feng, J. Z. Shen, S. H. Xie, Fuel, 2014, 122, 47-53.

[24] U. Oemar, Y. Kathiraser, L. Mo, X. Ho, S. Kawi, Catal. Sci. Technol., 2016, 6, 1173-1186.

[25] S. A. Theofanidis, V. V. Galvita, H. Poelman, G. B. Marin, ACS Catal., 2015, 5, 3028-3039.

[26] H. Ay, D. Üner, Appl. Catal. B, 2015, 179, 128-138.
[27] J. J. Liu, H. Q. Peng, W. M. Liu, X. L. Xu, X. Wang, C. Q. Li, W. F. Zhou, P. Yuan, X. H. Chen, W. G. Zhang, H. B. Zhan, ChemCatChem, 2014, 6, 2095-2104.

[28] D. P. Liu, X. Y. Quek, W. N. E. Cheo, R. Lau, A. Borgna, Y. H. Yang, J. Catal., 2009, 266, 380-390.

[29] F. Guo, J. Q. Xu, W. Chu, Catal. Today, 2015, 256, 124-129.

[30] N. H. Elsayed, N. R. M. Roberts, B. Joseph, J. N. Kuhn, Appl. Catal. B, 2015, 179, 213-219.

[31] U. Oemar, K. Hidajat, S. Kawi, Int. J. Hydrogen Energy, 2015, 40, 12227-12238.

[32] W. Chen, G. F. Zhao, Q. S. Xue, L. Chen, Y. Lu, Appl. Catal. B, 2013, 136-137, 260-268.

[33] W. Chen, W. Q. Sheng, F. H. Cao, Y. Lu, Int. J. Hydrogen Energy, 2012, 37, 18021-18030.

[34] W. Chen, W. Q. Sheng, G. F. Zhao, F. H. Cao, Q. S. Xue, L. Chen, Y. Lu, RSC Adv., 2012, 2, 3651-3653.

[35] T. Yamaguchi, Catal. Today, 1994, 20, 199-217.

[36] P. M. de Souza, R. C. Rabelo-Neto, L. E. P. Borges, G. Jacobs, B. H. Davis, U. M. Graham, D. E. Resasco, F. B. Noronha, ACS Catal., 2015, 5, 7385-7398.

[37] H. Xie, J. L. Lu, M. Shekhar, J. W. Elam, W. N. Delgass, F. H. Ribeiro, E. Weitz, K. R. Poeppelmeier, ACS Catal., 2012, 3, 61-73.

[38] Y. Han, J. F. Zhu, Top. Catal., 2013, 56, 1525-1541.

[39] Y. Q. Song, D. H. He, B. Q. Xu, Appl. Catal. A, 2008, 337, 19-28.

[40] M. Rezaei, S. M. Alavi, S. Sahebdelfar, P. Bai, X. M. Liu, Z. F. Yan, Appl. Catal. B, 2008, 77, 346-354.

[41] M. Rezaei, S. M. Alavi, S. Sahebdelfar, L. Xinmei, L. Qian, Z. F. Yan, Energy Fuels, 2007, 21, 581-589.

[42] X. P. Zhang, Q. P. Zhang, N. Tsubaki, Y. S. Tan, Y. Z. Han, Fuel, 2015, $147,243-252$.

[43] W. T. Zheng, K. Q. Sun, H. M. Liu, Y. Liang, B. Q. Xu, Int. J. Hydrogen Energy, 2012, 37, 11735-11747.

[44] J. S. Chang, D. Y. Hong, X. S. Li, S. E. Park, Catal. Today, 2006, 115, 186-190.

[45] B. Q. Xu, J. M. Wei, Y. T. Yu, Y. Li, J. L. Li, Q. M. Zhu, J. Phys. Chem. B, 2003, 107, 5203-5207.

[46] X. J. Du, D. S. Zhang, L. Y. Shi, R. H. Gao, J. P. Zhang, J. Phys. Chem. C, 2012, 116, 10009-10016.

[47] F. L. Liao, Y. Q. Huang, J. W. Ge, W. R. Zheng, K. Tedsree, P. Collier, X. Hong, S. C. Tsang, Angew. Chem. Int. Ed., 2011, 50, 2162-2165.

[48] X. Y. Huang, C. X. Dang, H. Yu, H. J. Wang, F. Peng, ACS Catal., 2015, $5,1155-1163$.

\section{Graphical Abstract}

Chin. J. Catal., 2016, 37: 2122-2133 doi: 10.1016/S1872-2067(16)62540-8

\section{Morphology effect of zirconia support on the catalytic performance of supported Ni catalysts for dry reforming of methane}

Weizuo Li, Zhongkui Zhao *, Yanhua Jiao, Guiru Wang Dalian University of Technology; Hangzhou Normal University

An immature pinecone shaped hierarchically structured zirconia is a promising support for $\mathrm{Ni}$-based catalysts for hydrogen production by the dry reforming of methane. The origin of its superior catalytic performance was discussed.

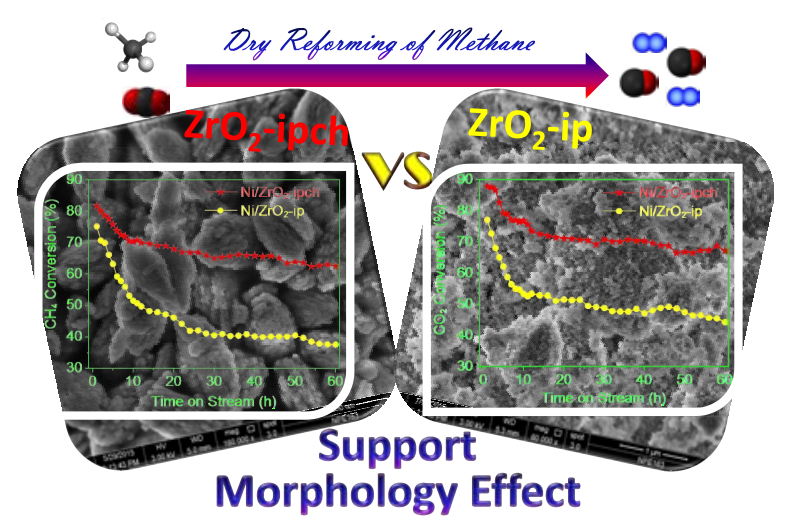


[49] P. Djinović, I. G. O. Črnivec, A. Pintar, Catal. Today, 2015, 253, 155-162.

[50] V. M. Gonzalez-Delacruz, F. Ternero, R. Pereñíguez, A. Caballero, J. P. Holgado, Appl. Catal. A, 2010, 384, 1-9.

[51] F. Wang, M. Wei, D. G. Evans, X. Duan, J. Mater. Chem. A, 2016, 4, 5773-5783.

[52] W. Z. Li, Z. K. Zhao, F. S. Ding, X. W. Guo, G. R. Wang, ACS Sustain. Chem. Eng., 2015, 3, 3461-3476.

[53] M. S. Fan, A. Z. Abdullah, S. Bhatia, Appl. Catal. B, 2010, 100, 365-377.

[54] J. B. Zhou, Z. Zhang, B. Cheng, J. Q. Yu, Chem. Eng. J., 2012, 211, 153-160.

[55] J. G. Yu, J. C. Yu, M. K. P. Leung, W. K. Ho, B. Cheng, X. J. Zhao, J. C. Zhao, J. Catal., 2003, 217, 69-78.

[56] K. L. Lü, Q. J. Xiang, J. Q. Yu, Appl. Catal. B, 2011, 104, 275-281.

[57] M. M. Barroso-Quiroga, A. E. Castro-Luna, Int. J. Hydrogen Energy, 2010, 35, 6052-6056.

[58] A. J. Zhang, A. M. Zhu, B. B. Chen, S. H. Zhang, C. T. Au, C. Shi, Catal. Commun., 2011, 12, 803-807.

[59] E. Baktash, P. Littlewood, R. Schomäcker, A. Thomas, P. C. Stair, Appl. Catal. B, 2015, 179, 122-127.

[60] N. Miletić, U. Izquierdo, I. Obregon, K. Bizkarra, I. AgirrezabalTelleria, L. V. Bario, P. L. Arias, Catal. Sci. Technol., 2015, 5, 1704-1715.

[61] J. L. Ewbank, L. Kovarik, F. Z. Diallo, C. Sievers, Appl. Catal. A, 2015, 494, 57-67.

[62] L. L. Xu, H. L. Song, L. J. Chou, ACS Catal., 2012, 2, 1331-1342.
[63] A. G. Bhavani, W. Y. Kim, J. S. Lee, ACS Catal., 2013, 3, 1537-1544.

[64] M. Rezaei, S. M. Alavi, S. Sahebdelfar, Z. F. Yan, Energy Fuels, 2008, 22, 2195-2202.

[65] K. Sutthiumporn, S. Kawi, Int. J. Hydrogen Energy, 2011, 36, 14435-14446.

[66] F. G. Wang, L. L. Xu, J. Zhang, Y. Zhao, H. Li, H. X. Li, K. Wu, G. Q. Xu, W. Chen, Appl. Catal. B, 2016, 180, 511-520.

[67] N. Wang, K. Shen, X. P. Yu, W. Z. Qian, W. Chu, Catal. Sci. Technol., 2013, 3, 2278-2287.

[68] W. Y. Kim, Y. H. Lee, H. Park, Y. H. Choi, M. H. Lee, J. S. Lee, Catal. Sci. Technol., 2016, 6, 2060-2064.

[69] M. A. Vasiliades, M. M. Makri, P. Djinovic, B. Erjavec, A. Pintar, A. M. Efstathiou, Appl. Catal. B, 2016, 197, 168-183.

[70] M. A. Naeem, A. Sadeq Al-Fatesh, A. H. Fakeeha, A. E. Abasaeed, Int. J. Hydrogen Energy, 2014, 39, 17009-17023.

[71] V. García, J. J. Fernández, W. Ruíz, F. Mondragón, A. Moreno, Catal. Commun., 2009, 11, 240-246.

[72] S. H. Zhang, S. Muratsugu, N. Ishiguro, M. Tada, ACS Catal., 2013, 3 , 1855-1864

[73] W. W. Yang, H. M. Liu, Y. M. Li, H. Wu, D. H. He, Int. J. Hydrogen Energy, 2016, 41, 1513-1523

[74] S. G. Liu, L. X. Guan, J. P. Li, N. Zhao, W. Wei, Y. H. Sun, Fuel, 2008, 87, 2477-2481.

[75] L. L. Xu, H. L. Song, L. J. Chou, Appl. Catal. B, 2011, 108-109, 177-190.

[76] N. N. Sun, X. Wen, F. Wang, W. Wei, Y. H. Sun, Energy Environ. Sci., 2010, 3, 366-369.

\title{
氧化锆担载镍甲烷干重整催化剂的载体形貌效应
}

\author{
李伟作 ${ }^{\mathrm{a}}$, 赵忠奎 ${ }^{\mathrm{a}}{ }^{*}$ ，焦艳华 ${ }^{\mathrm{b}}$ ，王桂茹 ${ }^{\mathrm{a}}$ \\ ${ }^{\mathrm{a}}$ 大连理工大学化工与环境生命学部精细化工国家重点实验室, 辽宁大连 116024

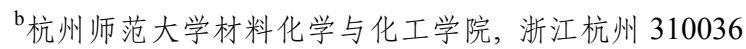

摘要: 煤层气是储量十分丰富的煤炭伴生资源, 也是煤炭开采中最大的安全隐患之一, 同时还是重要的温室气体. 研究煤 层气的高效、清洁资源化利用具有资源和环境双重意义. 因此, 世界主要产煤国均十分重视煤层气的开发和利用. 煤层气 的主要成分是甲烷, 目前主要通过两种方式实现其资源化利用: (1) 直接转化, 主要通过氧化偶联、催化氧化官能团化或脱 氢芳构化等途径将其转化为高碳烃、含氧化合物及芳烃等; (2) 间接转化, 甲烷首先经催化重整反应制取合成气, 而后再经 Fischer-Tropsch 合成、甲醇化和氢甲酰化等过程来合成饱和烃、烯烃、甲醇及其他含氧化物. 对于前者, 由于热力学限制, 反应收率很低, 应用前景较差, 而经由合成气这一平台产物的间接转化路线被认为是一条甲烷资源化利用颇具工业前景的 转化路线. 因此, 甲烷催化重整制合成气备受关注.

研究表明, 贵金属具有较好的甲烷重整催化性能, 但其储量有限、价格昂贵的内在缺陷不利于甲烷大规模转化和资源 化利用. $\mathrm{Ni}$ 基催化剂具有与贵金属可比的催化活性和选择性, 且其储量丰富, 价格低廉, 因此在甲烷重整反应中备受青睐. 但是, 相对于贵金属, $\mathrm{Ni}$ 基催化剂易于积碳和烧结失活, 这已成为制约其大规模工业化应用的瓶颈. 迄今, 大量文献报道关 注如何提高 $\mathrm{Ni}$ 基催化剂的催化稳定性. 而载体形貌调控是调节负载型催化剂的有效途径. 本文开展了用作载 $\mathrm{Ni}$ 催化剂 的氧化锆载体的形貌调控研究, 以期可以有效调节载 $\mathrm{Ni}$ 催化剂的物化性质, 进而调控载 $\mathrm{Ni}$ 催化剂的甲烷重整催化性能.

采用水热法成功制备了松球状和鹅卵石状的单斜相氧化锆载体, 进一步负载镍, 制备了载镍催化剂, 用于甲烷重整制 合成气反应. 具有分级结构的松球状氧化锆载 $\mathrm{Ni}$ 催化剂 $\left(\mathrm{Ni} / \mathrm{ZrO}_{2}-\mathrm{ipch}\right)$ 展示出比鹅卵石状氧化锆和常规氧化锆纳米粒子 载 $\mathrm{Ni}$ 催化剂显著好的催化活性和稳定性. 采用 XRD、 $\mathrm{N}_{2}$ 吸附、TEM、 $\mathrm{H}_{2}-\mathrm{TPR} 、 \mathrm{CO}$ 化学吸附、 $\mathrm{CO}_{2}-\mathrm{TPD} 、 \mathrm{XPS}$ 和TGA 等 手段研究了松球状氧化锆载 $\mathrm{Ni}$ 催化剂高催化活性和稳定性的原因和机制. 发现, 其较高的催化活性主要归因于高的 $\mathrm{Ni}$ 分散度、改善的可还原性、促进的氧流动性以及较多的碱性位和较强的碱性, 这些物化性质依赖于氧化锆载体的独特形貌. 分级结构的松球状氧化锆载 Ni 催化剂高的甲烷重整催化稳定性主要源于催化剂的高抗烧结、抗积碳性能. 加强的金属载 体效应和介孔限域效应可以阻止金属 $\mathrm{Ni}$ 的高温烧结, 而优良的抗积碳稳定性主要源于催化剂良好的氧流动性、较多的碱 性位、较强的碱性以及小的 $\mathrm{Ni}$ 粒子尺寸. 
鉴于分级结构松球状氧化锆载 $\mathrm{Ni}$ 催化剂高的催化活性和优良的抗积碳、抗烧结稳定性, 该催化剂用于甲烷重整制合 成气具有广阔前景. 而所制备的分级结构松球状氧化铅由于具有独特的结构和优良的热稳定性, 可以作为性能优良的载 体用于其他反应, 尤其对于高温转化过程可望表现出明显优势.

关键词：镍基催化剂; 氧化锆载体; 分级结构; 形貌效应; 甲烷干重整; 合成气；抗积碳

收稿日期: 2016-08-29. 接受日期: 2016-09-30. 出版日期: 2016-12-05.

*通讯联系人. 电话/传真: (0411)84986354; 电子信箱: zkzhao@dlut.edu.cn

基金来源：国家自然科学基金-煤炭联合基金(U1261104); 国家自然科学基金 (21276041); 教育部新世纪优秀人才支持计划 (NCET-12-0079); 辽宁省自然科学基金 (2015020200); 中央高校基本科研业务费专项资金(DUT15LK41); 杭州市科技发展计划 (20130533B14).

本文的英文电子版由Elsevier出版社在ScienceDirect上出版(http://www.sciencedirect.com/science/journal/18722067). 